\title{
جماليات خط المسند والاستفادة هنه في إثراء ملابس المرأة
}

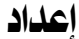 \\ همت محمد فيومحسـ محمد \\ أستاذ مساعد تصنيع ملابس بقسم الاقتصاد المنزلي \\ كلية التربية - جامعة نجران
}

مجلة بحوث التربية النوعية ـ جامعة المنصورة

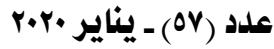




\title{
جماليات خط المسند والاستفادة هنه في إثراء هلابس المرأة
}

\author{
(إعداد \\ همت محمد فيوميمحمد
}

טمال|l|

يعتبر تصميه الأزياء من الفنون التشكيلية الجميلة عندما يرتبط بالفنون الأخرى وخاصة

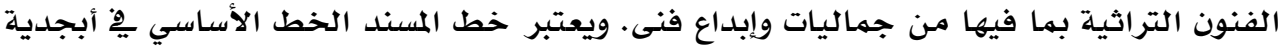

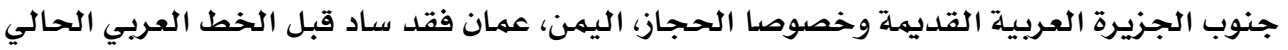

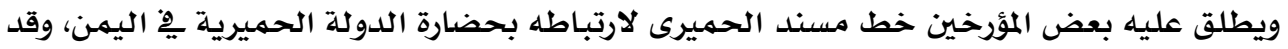

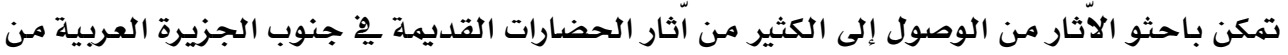

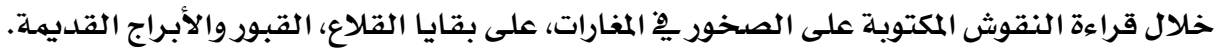
وتتلخص مشكلة البحث ِِِ ندرة الاستفادة من الجماليات التي تمتلكها حروف خط المسند

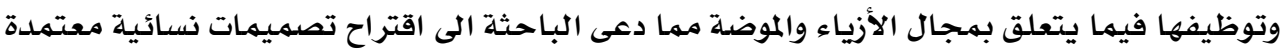

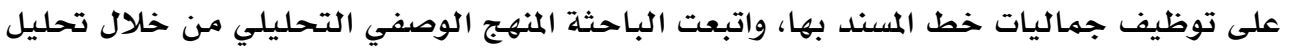

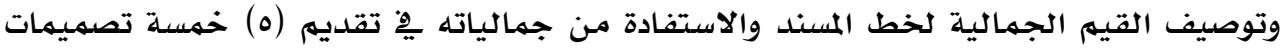

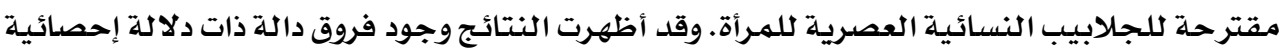

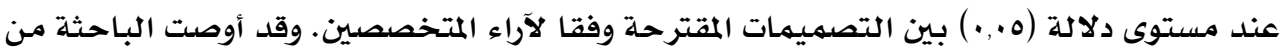

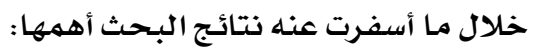

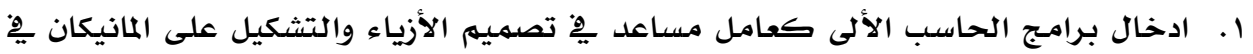

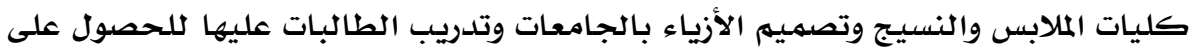

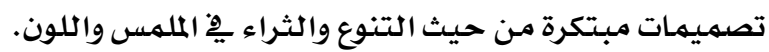

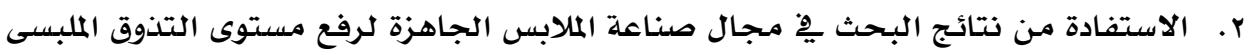
لدى المرأة.

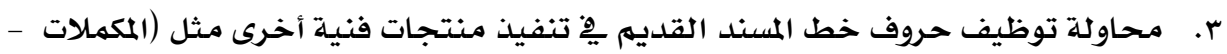
قطع ملبسية اخرى). الكلمات المفتاحية: جماليات خط المسند - ملابس المرأة.

مقدمه

يعتبر خط المسند الخط الأساسي ِِِ أبجدية جنوب الجزيرة العربية القديمة وخصوصا

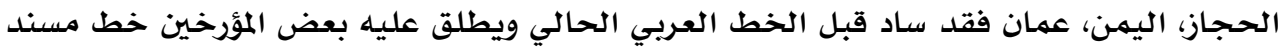

" أستاذ مساعد تصنيع ملابس بقسم الاقتصاد المنزلي كلية التربية - جامعة نجران 
الحميرى لارتباطه بحضارة الدولة الحميرية يِّ اليمن، وقد تهكن باحثو الآثار من الوصول إلى الكثير

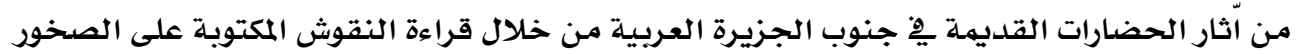
يِّ المغارات، على بقايا القلاع، القبور والأبراج القديمة الجية. وحروف المسند تتكون من مجموعة من الخطوط المجردة والمستقيمة واللينة تصنع تركيباتها

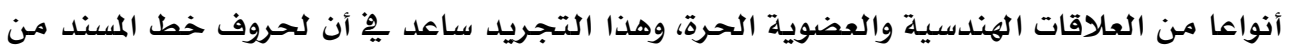

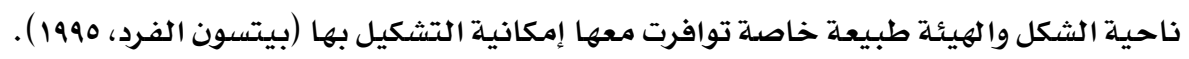

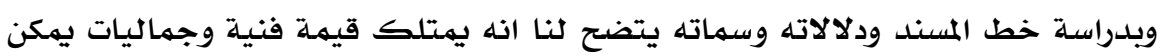

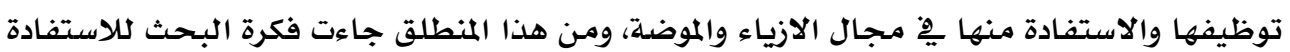

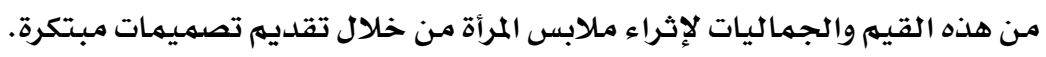
مشكلة البحث هلده القيثر

تتلخص مشكلة البحث ٌِِ ندرة الاستفادة من الجماليات التي تمتلكها حروف خط المسند وتوظيفها

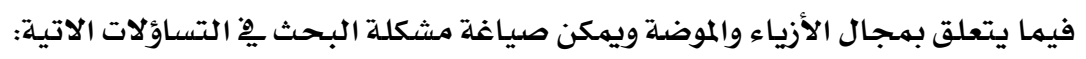

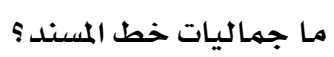

ما امكانية الاستفادة من جماليات خط المسند يِّ اثراء مـلابس المرأة من خلال تقديم

$$
\text { تصميمات مبتكرة؟ ما امكانية الاستفادة مئ }
$$

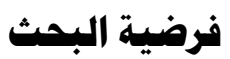

توجد فروق دالة احصائيا بين التصميمات المقترحة يِّ كلا من (الجانب الجمالي الجانب الوظيفي) وفقا لآراء المتخصصيا بين التصني

$$
\text { أهداف البحث }
$$

التعرف على نشأة وسمات وخصائص وجماليات خط المسند القديم ودوره كمصدر لإلهام

$$
\text { كثير من مصممي الأزياء. }
$$

ريط الأصالة بالمعاصرة والحداثة بالتراث من خلال الألاستفادة من جماليات حروف خط

المسند.

محاولة الوصول إلى مفهوم جديد يدعم الابتكارية والتجديد والانطلاق نحو افاق العصر

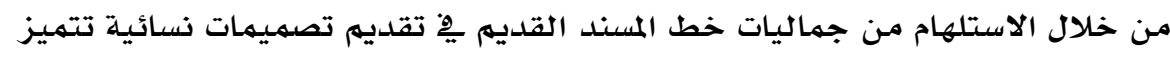
بالأصالة العربية. محاولة البحث ِِّ كيفية الاستفادة من القيم التشكيلية والجمالية لاستخلاص أشكال

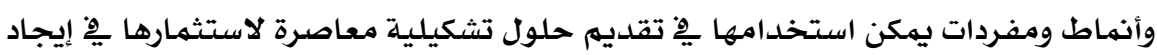

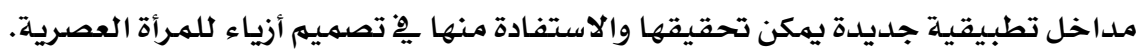

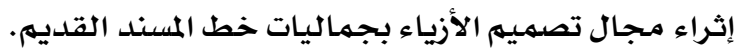




\section{تمثلت أهمية البحث هِِ التالي:}

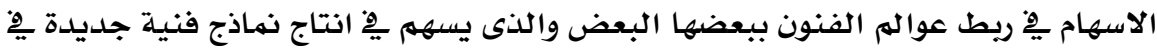

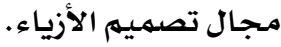

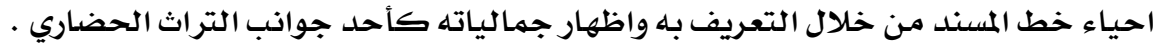

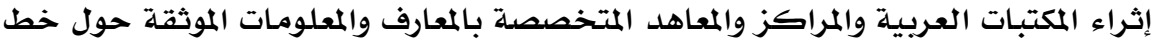
المسند القديهم. محاولة إيجاد نمط يساعد على تصميهم وإنتاج طراز جديد لكأزياء وإثرائه بخط المسند

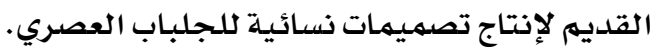
هنهمج البمث

\section{اتبعت الباحثة المنهج الوصفي التحليلي ويشتمل على:}

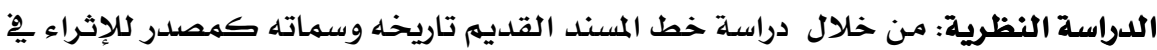

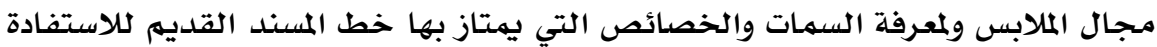

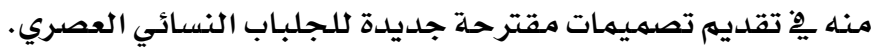

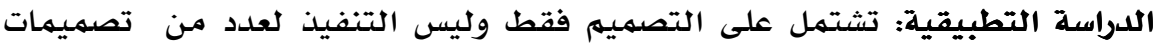

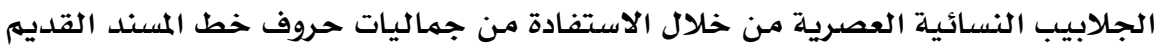

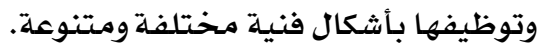
هدود البمث

الحدود الموضوعية: استخدام حروف خط المسند القديم كقيمة تراثية يِّ تقديم تصميمات

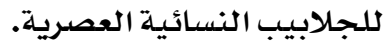

\section{هصطات البحث}

خط المسند:

هو نظام كتابة قديم تطور يِّ جنوب الجزيرة العربية (اليمن والمناطق الغربية لعمان

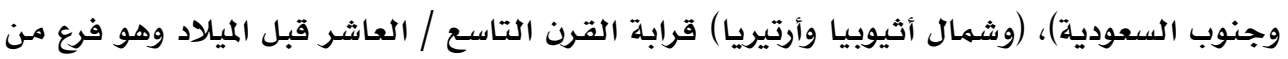

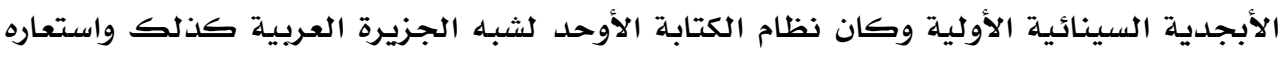

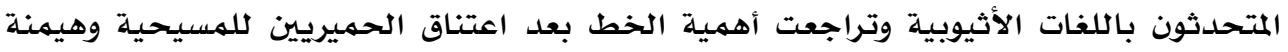
الأبجدية السريانية على أجزاء واسعة من الجزيرة العربية أواسط القرن الميلادي الرابع (بيتسون

\section{الإطار النظري لاببمث البمرد}

تعد الكتابة من اهم الإنجازات الحضارية التي توصل إليها الإنسان يِّ تاريخه الطويل

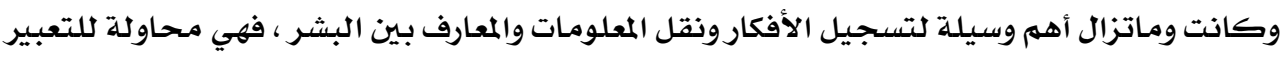


عن اللغة يِّ واقعها الصوتي لكنها غير قادرة ِِ أحيان كثيرة عن التعبير عن أصوات اللغة جميعها

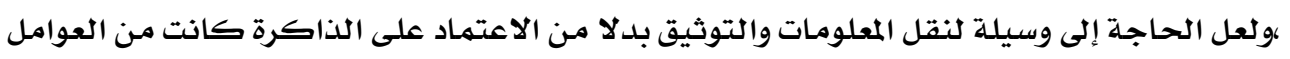

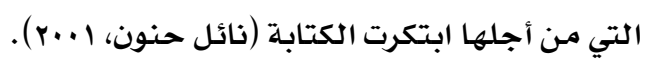

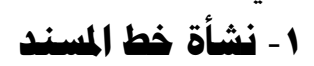

عرف المؤرخون واللغويون القدماء كلممة (المسند) وكان معناها واضحا لديهم على نحو المان

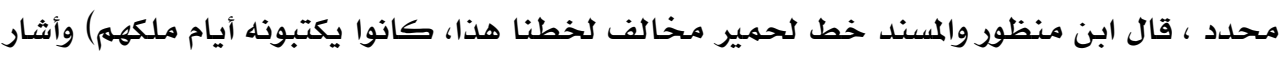

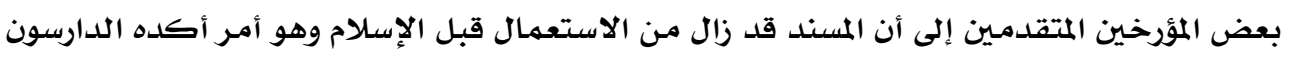

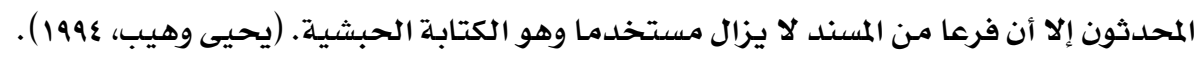

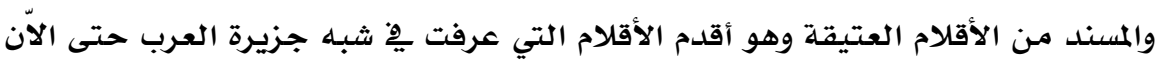

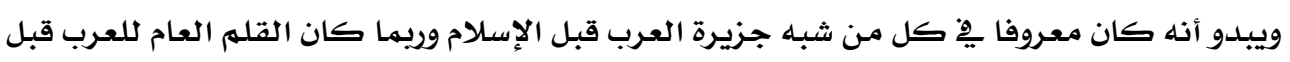

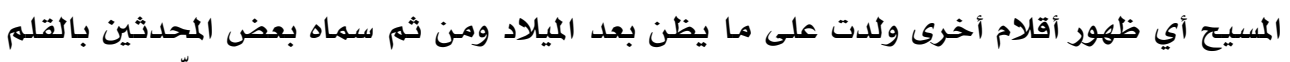

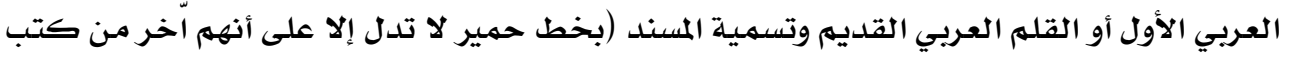

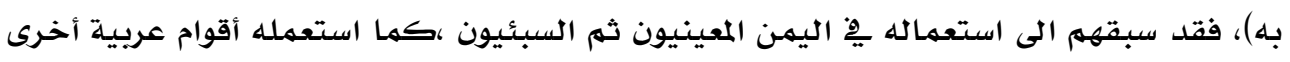

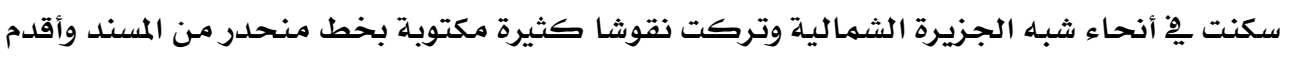

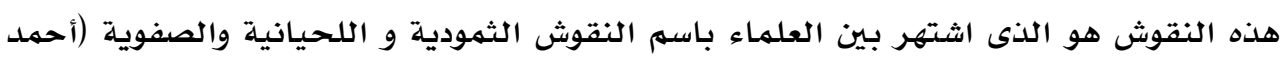
شوحان، (r... (r).

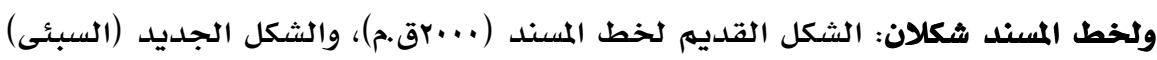

لخط المسند ( ..بق.م). والشكل (1) والشكل (r) يوضحان ذلك: (Marie and et.al, 2011).

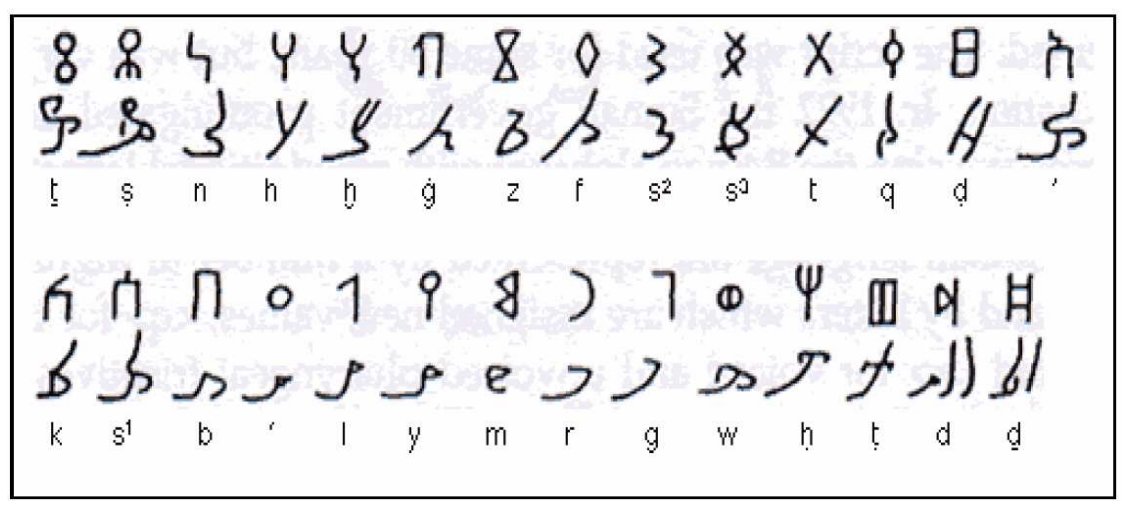

شكل (1) الشكل القديم لخط المسند 


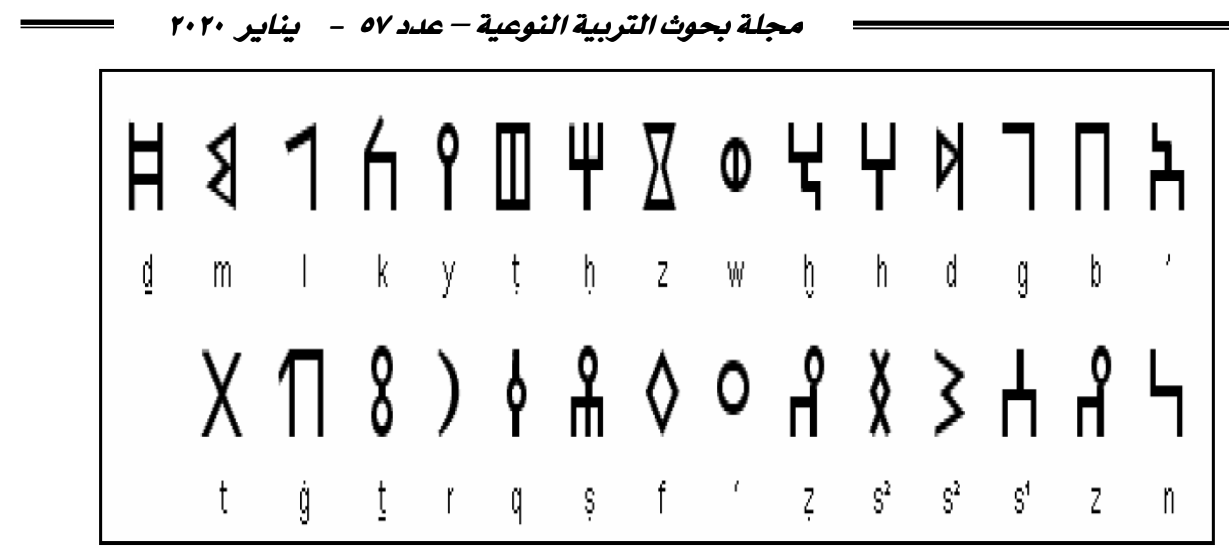

شكل (r) الشكل الجديد لخط المسند

إن الكتابة العربية الجنوبية التي كتبت بها نقوش الممالك اليمنية القديمة (سبأ، معين،

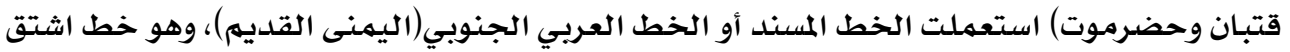

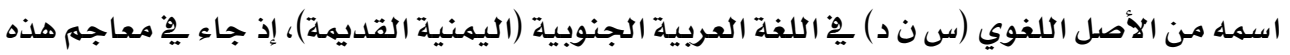

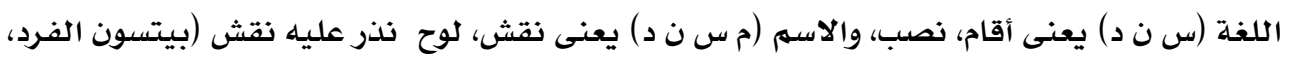
. (1914r وقد جاءت كلمة (م س ن د) ِِِ اللغة العربية الجنوبية بالسـين الثانية (السـامـخ) التي

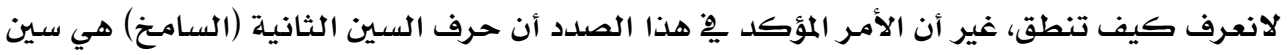

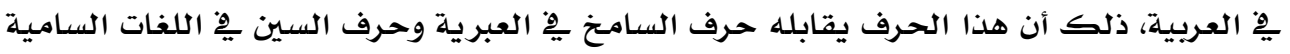

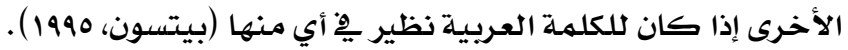

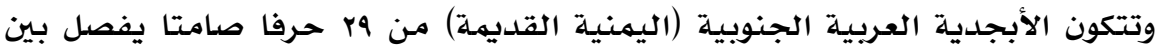

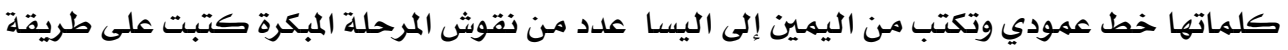

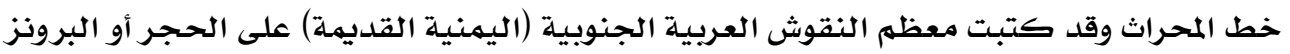

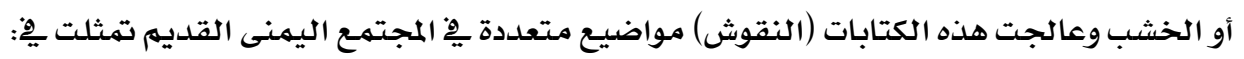

$$
\begin{aligned}
& \text { نصوص دينية وهى أكثر عددا وأهمية. }
\end{aligned}
$$

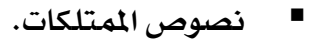

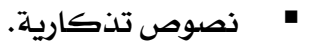

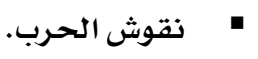

نقوش شعرية ذات طبيعة دينية. (كريستيان روبان، 1910)

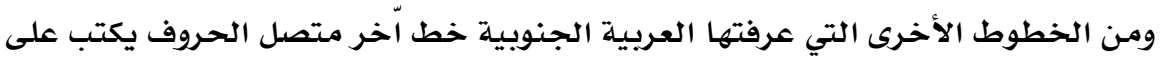

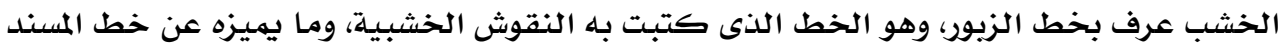

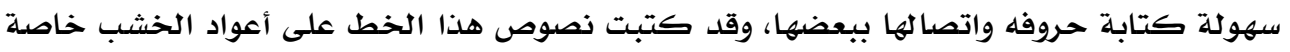

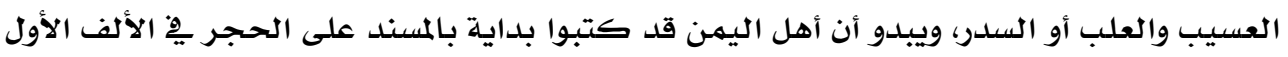


قبل الميلاد ثم استخدموا الخشب للكتابة من أجل المعاملات اليومية وريما كانت الكتابة على الحجر

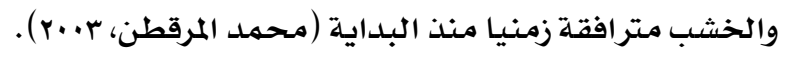

وقد سهى خط المسند بهذا الاسم لأن حروفه ترسهم على هيئة خطوط مستندة إلى أعمدة

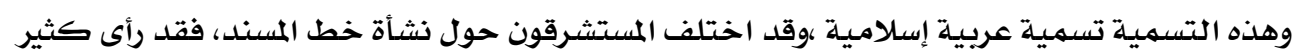

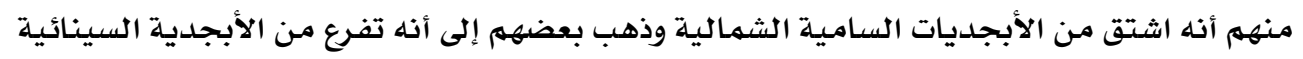

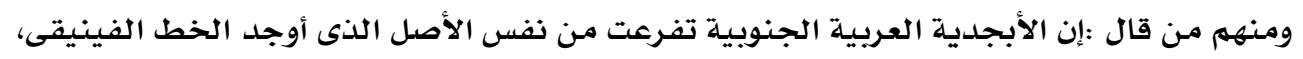

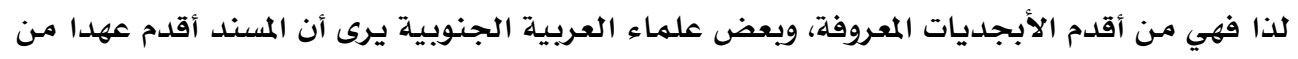

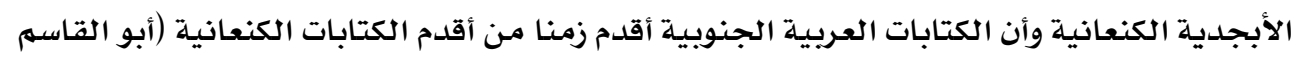

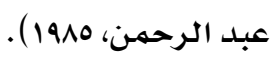

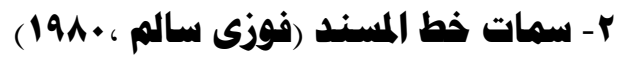

تتألف ابجدية المسند من وبحرفا وهى حروف صامتة أبي خالية من حروف الترميز الى

$$
\text { حركات }
$$

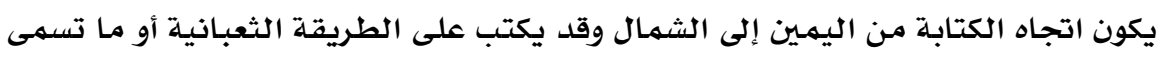

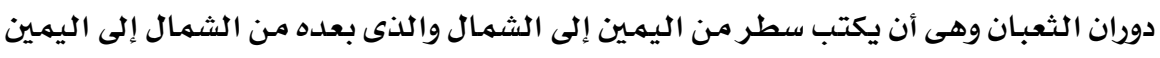

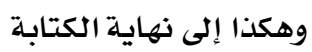

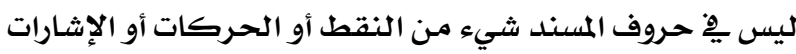

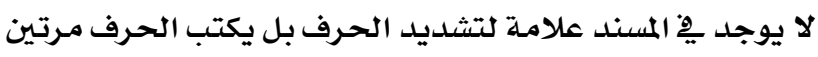

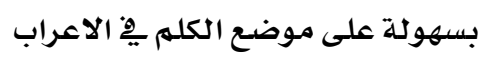

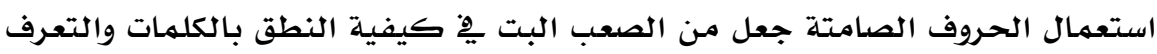

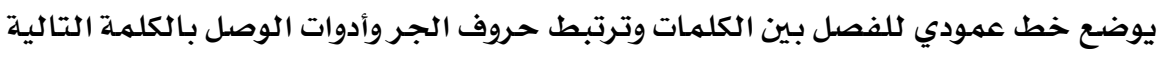

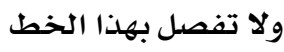

\section{r- التعريف بالنقوش المسندية}

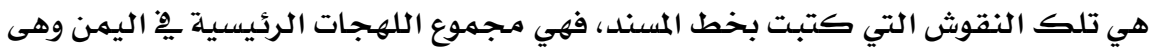

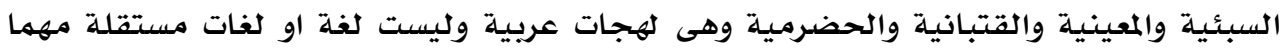

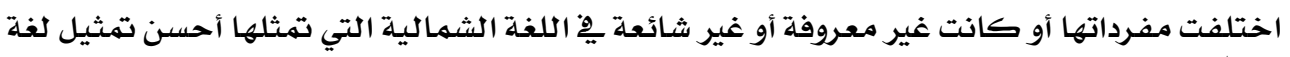

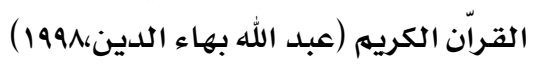

\section{ويمكن تقسيم هذه النقوش إلى أربع مجموعات:}

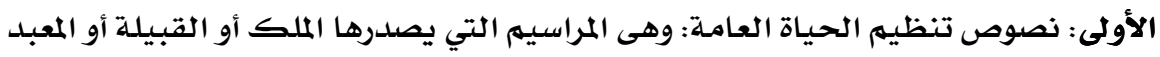

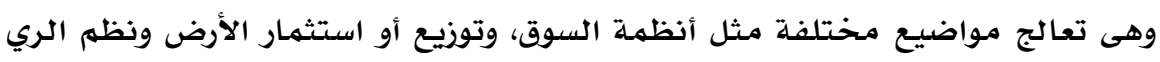

$$
\text { ودخول المعبد وغيرها. }
$$




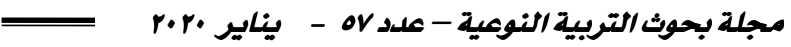

الثانية: نصوص دينية مثل نقوش الهبات والقرابين والاعترافات العلنية وغيرها وهى أكثر

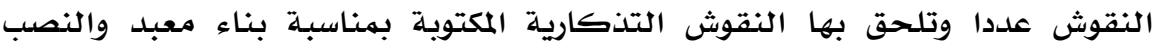
الجنائزية.

الثالثة: نصوص متعلقة بالممتلكات وهى نقوش تتعلق بمناسبة إقامـة منشآّ أو توسيعها

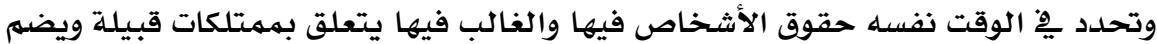

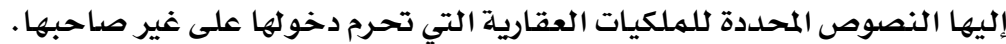

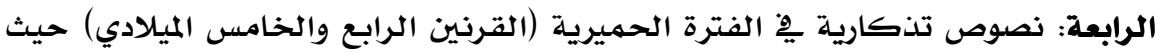

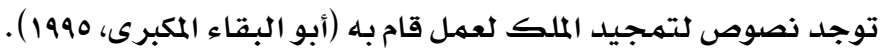
أدوات البمث توجث

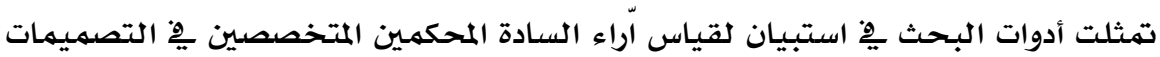

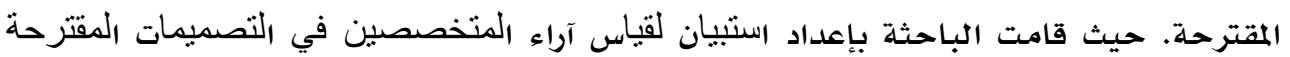

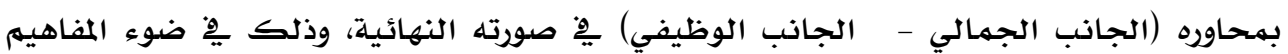

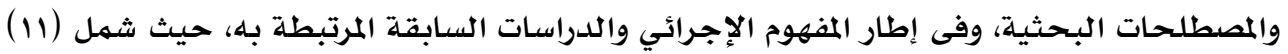

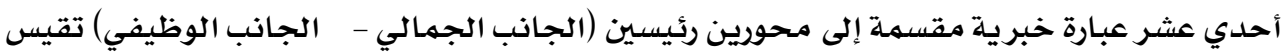

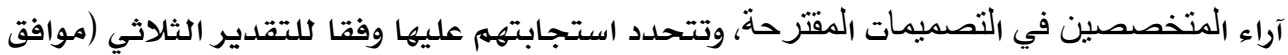

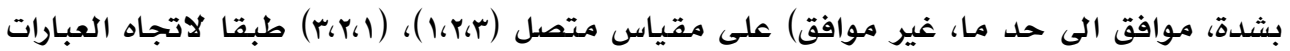

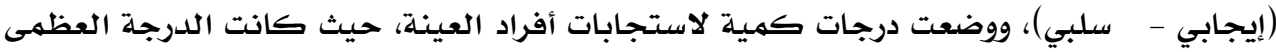

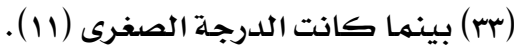

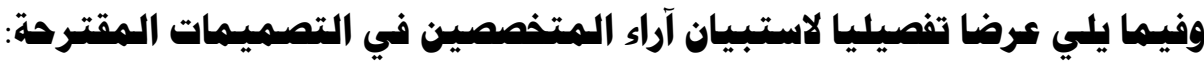

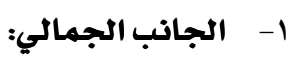

اشتهل هذا المحور على (v) عبارات خبرية تقيس مستوى الجانب الجمالي في التصميمات

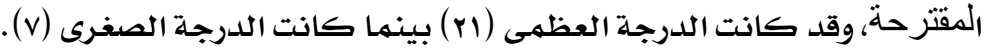

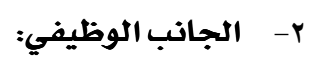

اشتمل هذا المحور على (ع) عبارات خبرية تقيس مستوى الجانب الوظيفي في التصميمات

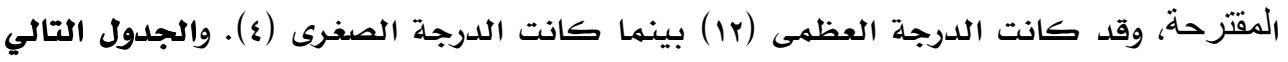
يوضتح الاستبيان: 
جلدول (1) استبيان تحكيم التصميمات المقترحة

\begin{tabular}{|c|c|c|c|c|}
\hline \multicolumn{3}{|c|}{ عبارات التقييي } & \multirow{2}{*}{ 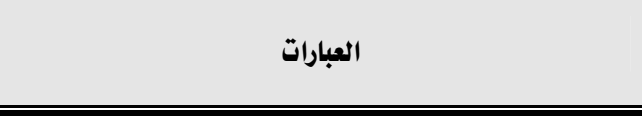 } & \multirow{2}{*}{ s } \\
\hline 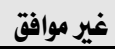 & 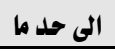 & موافق بشدة & & \\
\hline \multicolumn{5}{|c|}{ اولاً: الجانب الجمالي: } \\
\hline & & & تظهر جماليات وسمات خط المسند بروح معاصرة في التصميم & 1 \\
\hline & & & 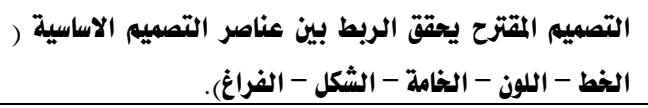 & r \\
\hline & & & التصميم المقترح يحقق نوعاً ما من الحداثة والاصالة. & $r$ \\
\hline & & & حروف خط المسند حققت دور اساسي وجمالي في التصميه. & $\varepsilon$ \\
\hline & & & تتوافق الوان التصميم المقترح مع بعضها. & 0 \\
\hline & & & التصميم المترح حيتماشى مع اتجاهات الموضة السائدة. & 1 \\
\hline & & & التصميم المقترح له دور جمالي في اثراء العباءة النسائية. & $r$ \\
\hline \multicolumn{5}{|c|}{ ثانياً: الجانب الوظيفي: } \\
\hline & & & يصلح التصميم المترح حلان يكون منتجاً يمكن تطبيقه وتنفيذه. & 1 \\
\hline & & & يصلح التصميم المقترح لان يكون منتجاً يمكن تسويقه. & r \\
\hline & & & يمكن تنفيذ التصميم المقترح لمناسبات متنوعة. & r \\
\hline & & & يتماشى التصميم المقترح مع الفئة العمرية من النساء من سن ro & $\varepsilon$ \\
\hline
\end{tabular}

صدق وثبات أداة البحث:

أولا: صدق الاستبيان:

للتأكد من صدق الاستبيان قامت الباحثة بالاعتماد على طريقتين:

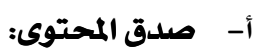

للتأكد من صدق المحتوى تم عرض استبيان آراء المتخصصين في التصميمات المقترحة فِيِ

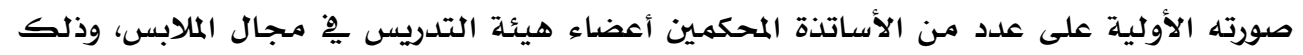

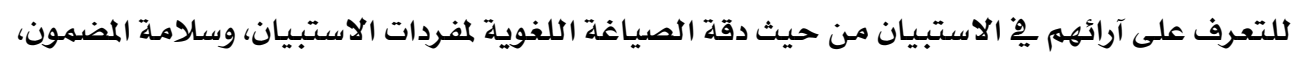

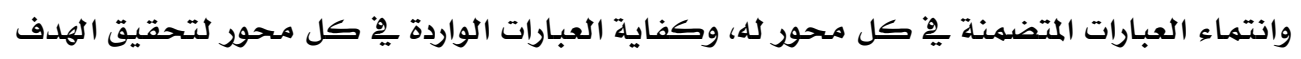

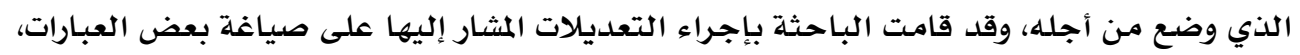

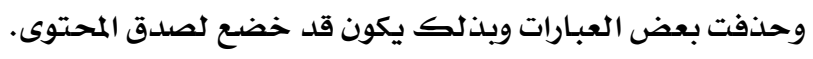

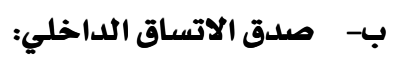




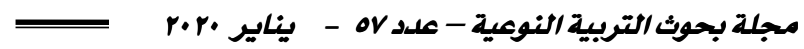

لحساب صدق الاتساق الداخلي لاستبيان آراء المتخصصين في التصميمات المقترحة، تم

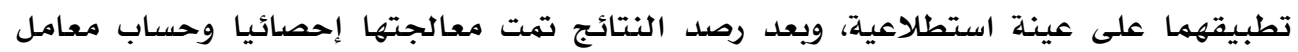

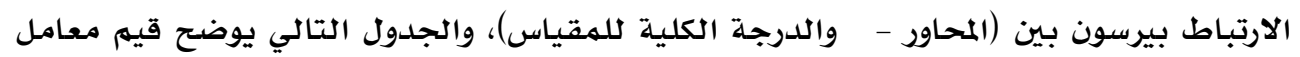
الارتباط:

جدول (ץ) معاملات الارتباط لاستبيان آراء المتخصصين في التصميمات المقترحة بين (المحاور والدرجة الكلية للاستبيان) ن=واء أنوان

\begin{tabular}{|c|c|c|c|}
\hline مستوى الدلاكة & معامل الارتباط & عدد العبارات & محاور الاستبيان \\
\hline$\cdot, \cdot 1$ & $* *, \wedge \mathrm{VV}$ & V & الجانب الجمالي \\
\hline$\cdot \cdot \cdot 1$ & $* *, \Lambda \cdot r$ & $\varepsilon$ & جانب الوظيفي \\
\hline
\end{tabular}

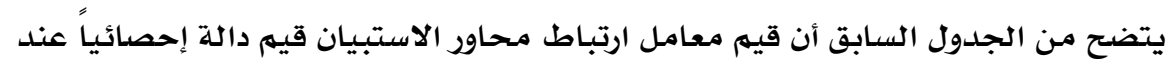

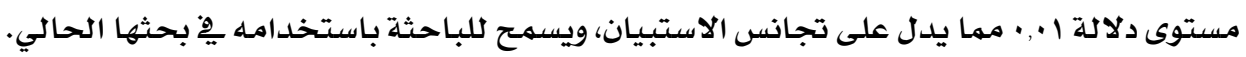
ثانيا: هساب ثبات الاستبيان Reliability

قامت الباحثة بحساب معاملات الثبات لاستبيان آراء المتخصصين في التصميمات المقترحة

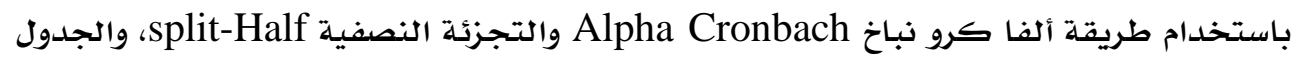
التالي يوضنح ذلك:

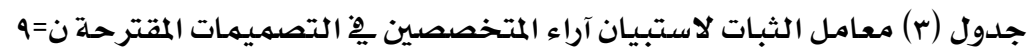

\begin{tabular}{|c|c|c|c|c|}
\hline \multicolumn{2}{|c|}{ التجزئة النصفية } & \multirow{2}{*}{ معامل ألفا } & \multirow{2}{*}{ عدد العبارات } & \multirow{2}{*}{ محاور المقياس } \\
\hline جتمان & سيبرمان & & & \\
\hline$\cdot$, VAY & $\cdot, \vee \wedge \varepsilon$ & $\cdot, \wedge \cdot 1$ & $\checkmark$ & الجانب الجمالي \\
\hline$\cdot, \mathrm{VA \Lambda}$ & $\cdot, \mathrm{V} \vee \mathrm{V}$ & 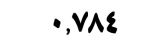 & $\varepsilon$ & الجانب الوظيفي \\
\hline$\cdot, \wedge \leqslant 1$ & $\cdot, \wedge \varepsilon 1$ & •,^९६ & 11 & ككل \\
\hline
\end{tabular}

يتضح من الجدول السابق أن قيم معاملات ثبات (ألفا - التجزئة النصفية والتي تشمل

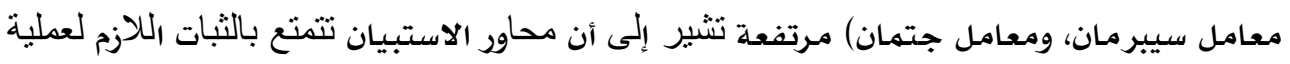

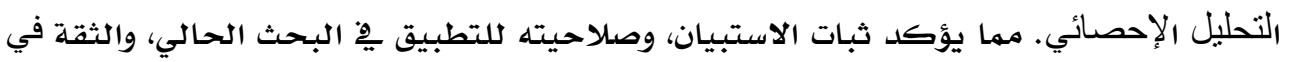
النتائج 


\section{جماليات خط /المسند والاستفادة منه يِ اثراء ملابس المراة \\ التصميميسمات الإقترحة}

قامت الباحثة باقتراح خمسة تصميمات للجلابيب النسائية العصرية المعتمدة على استخدام حروف خط المسند القديهم وتوظيفها بأشكال وأحجام متنوعة والتي تصلح للفئة العمرية من (مإلىهr) سنة توضح من خلالهم مدى الاستفادة من جماليات خط المسند لإثراء الجلباب،

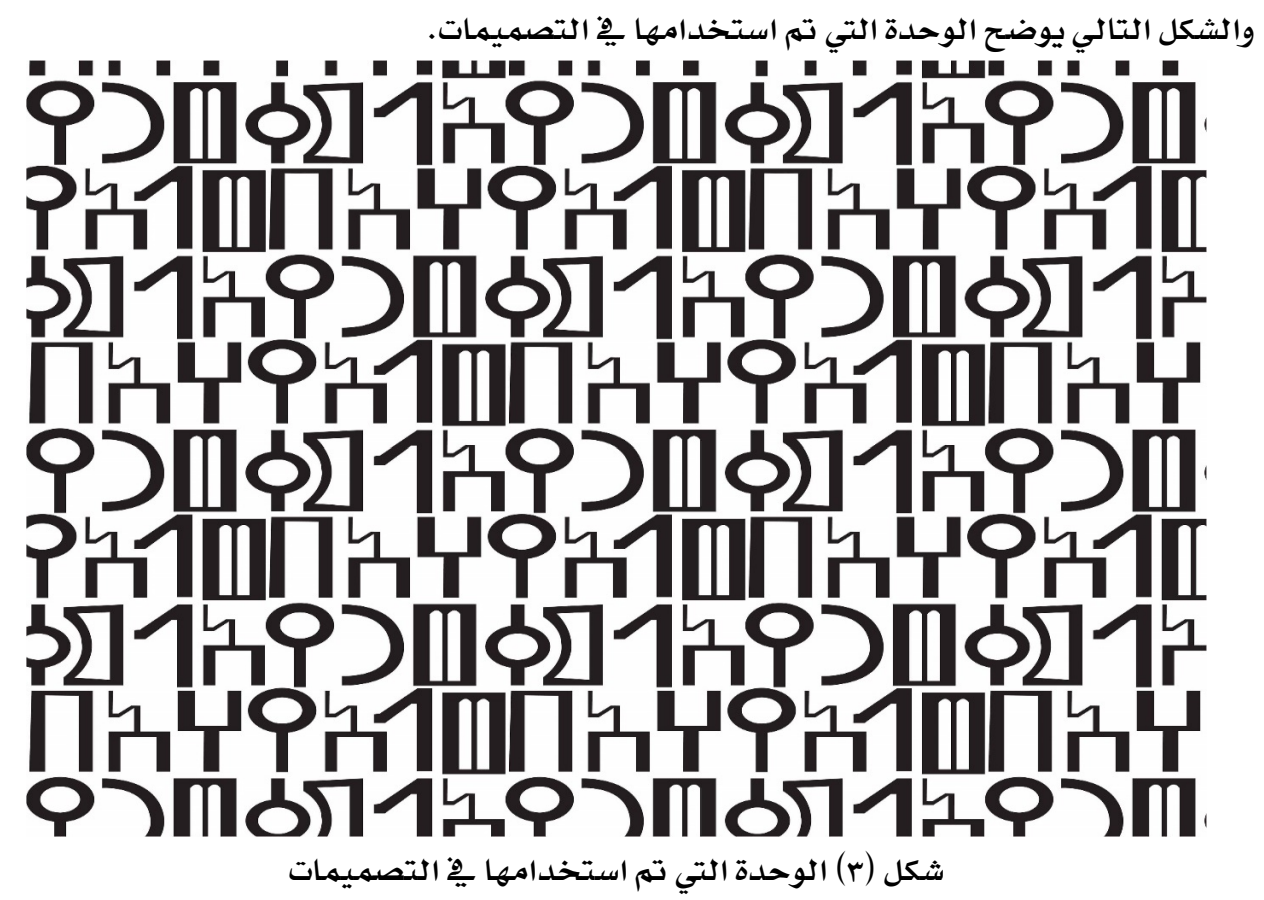

وقد استخدمت الباحثة برنامج Marvelous Designer مِّ عمل تلك التصميمات كهما هي في مبينة كالتالي: 

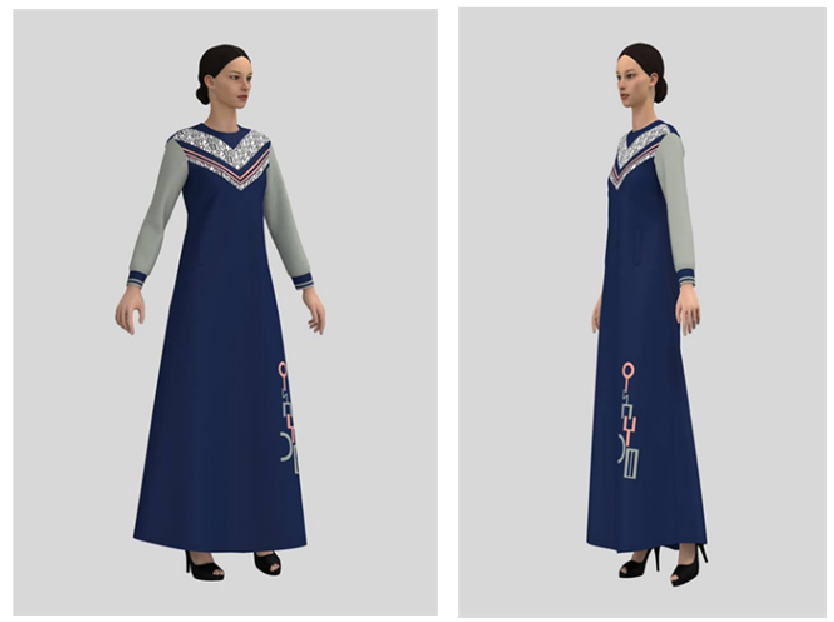

التصميم الأول:

$$
\begin{aligned}
& \text { شكل (ع) التصميم الأول } \\
& \text { والجدول التالي يوضح بنود التوصيف للتصميم الأول: }
\end{aligned}
$$

\begin{tabular}{|c|c|}
\hline التصميم الاول & بنود التوصيف \\
\hline 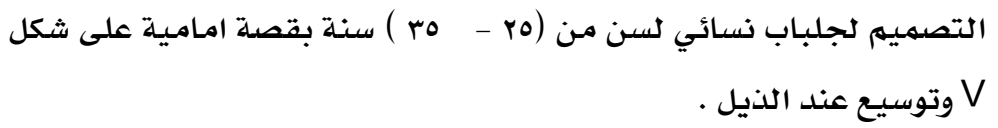 & توصيف الموديل \\
\hline والمسند. لك على جنب الجلباب اسفل خط الركبة بشكل طولي لجروف خط & جماليات خط الاستفادة من \\
\hline
\end{tabular}

جدول (ع) بنود توصيف التصميهم الأول 


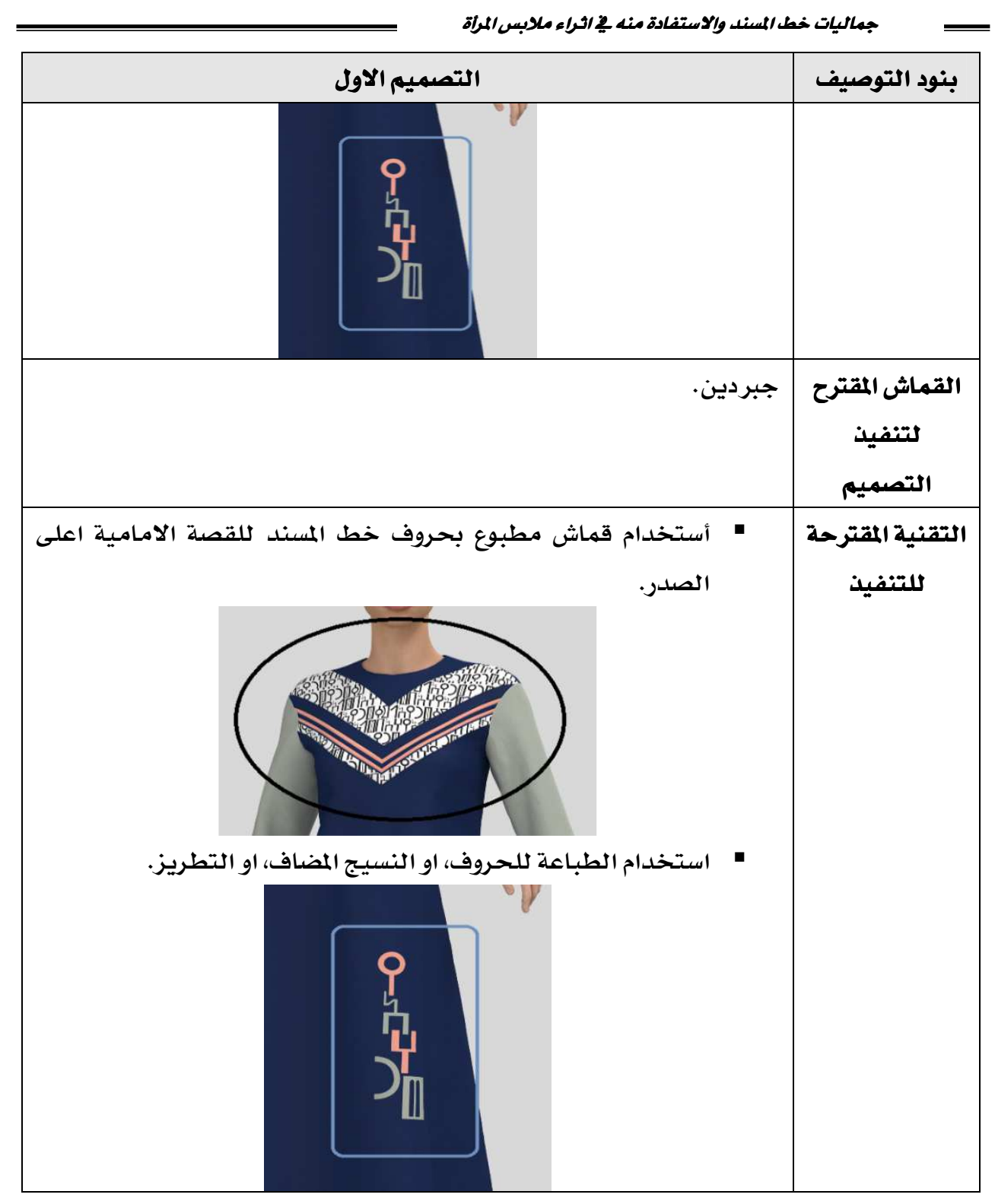



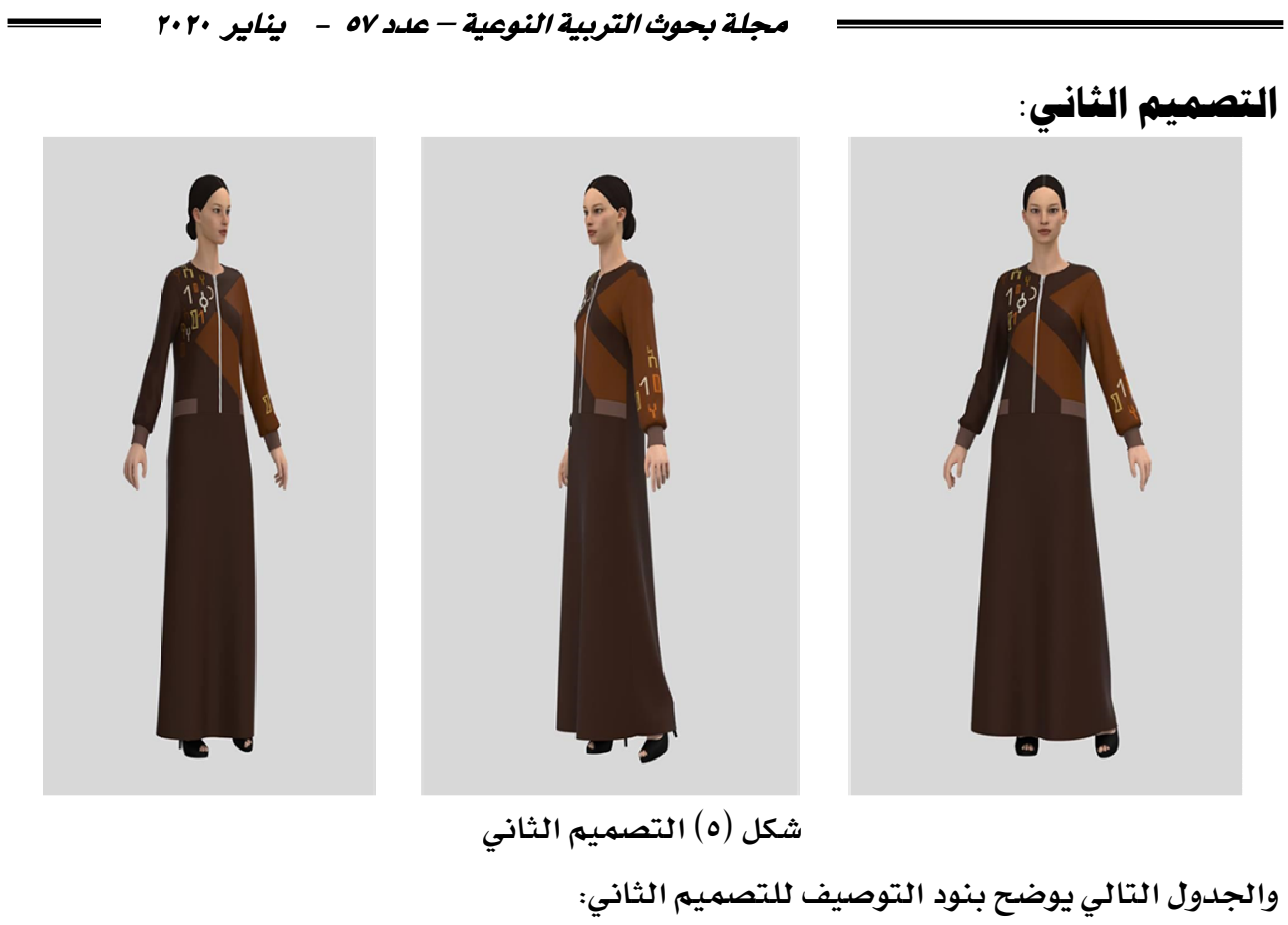

جدول (0) بنود توصيف التصميم الثاني

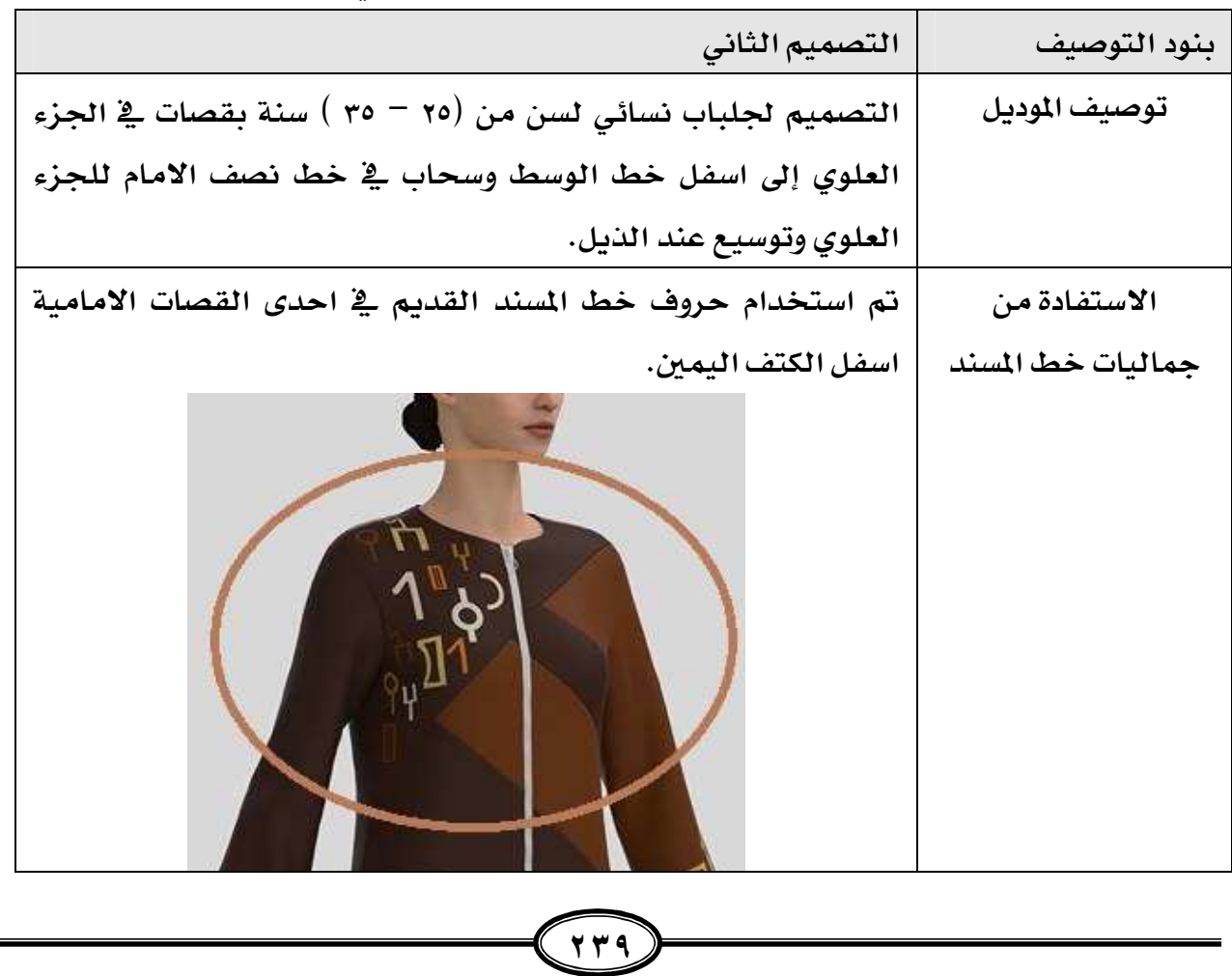




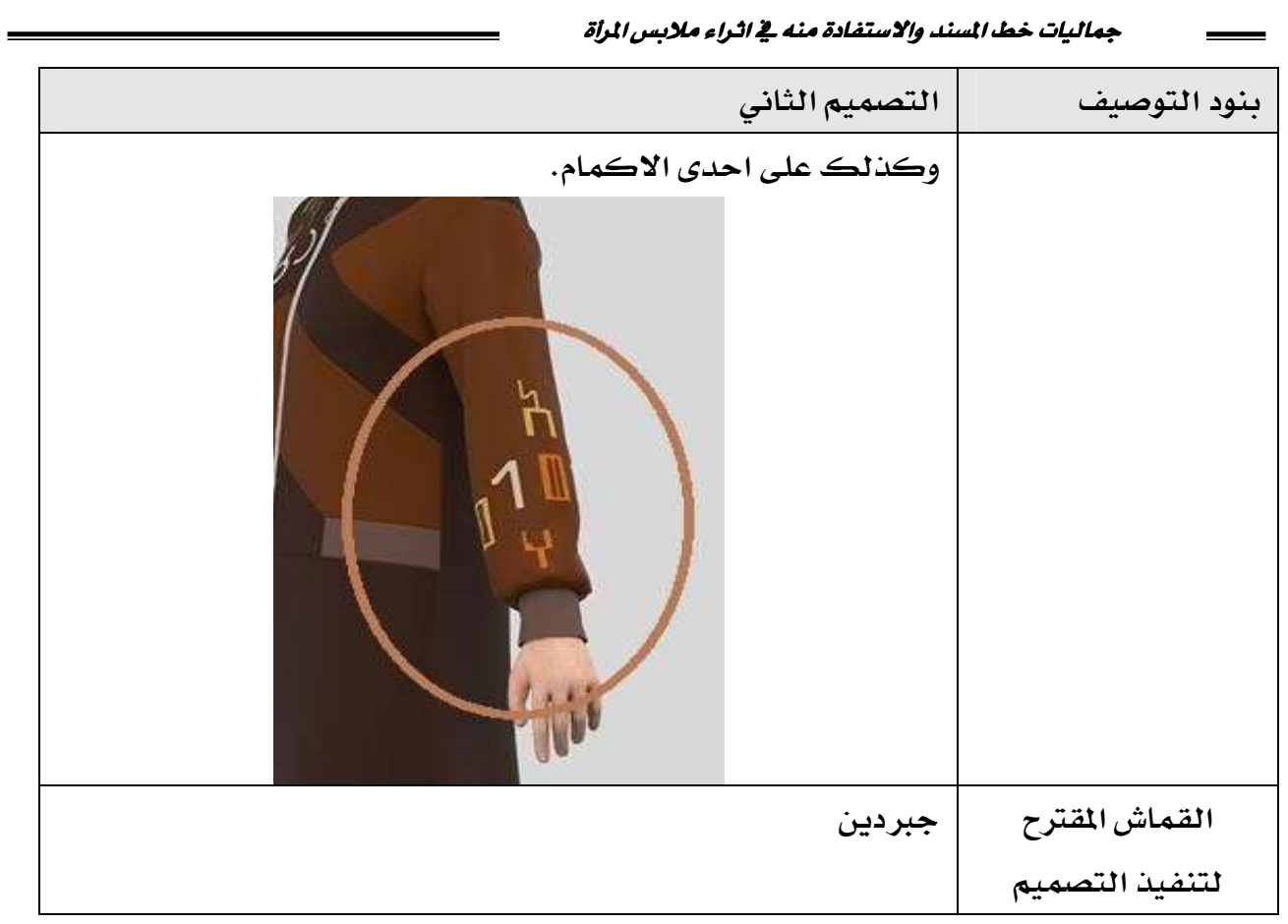




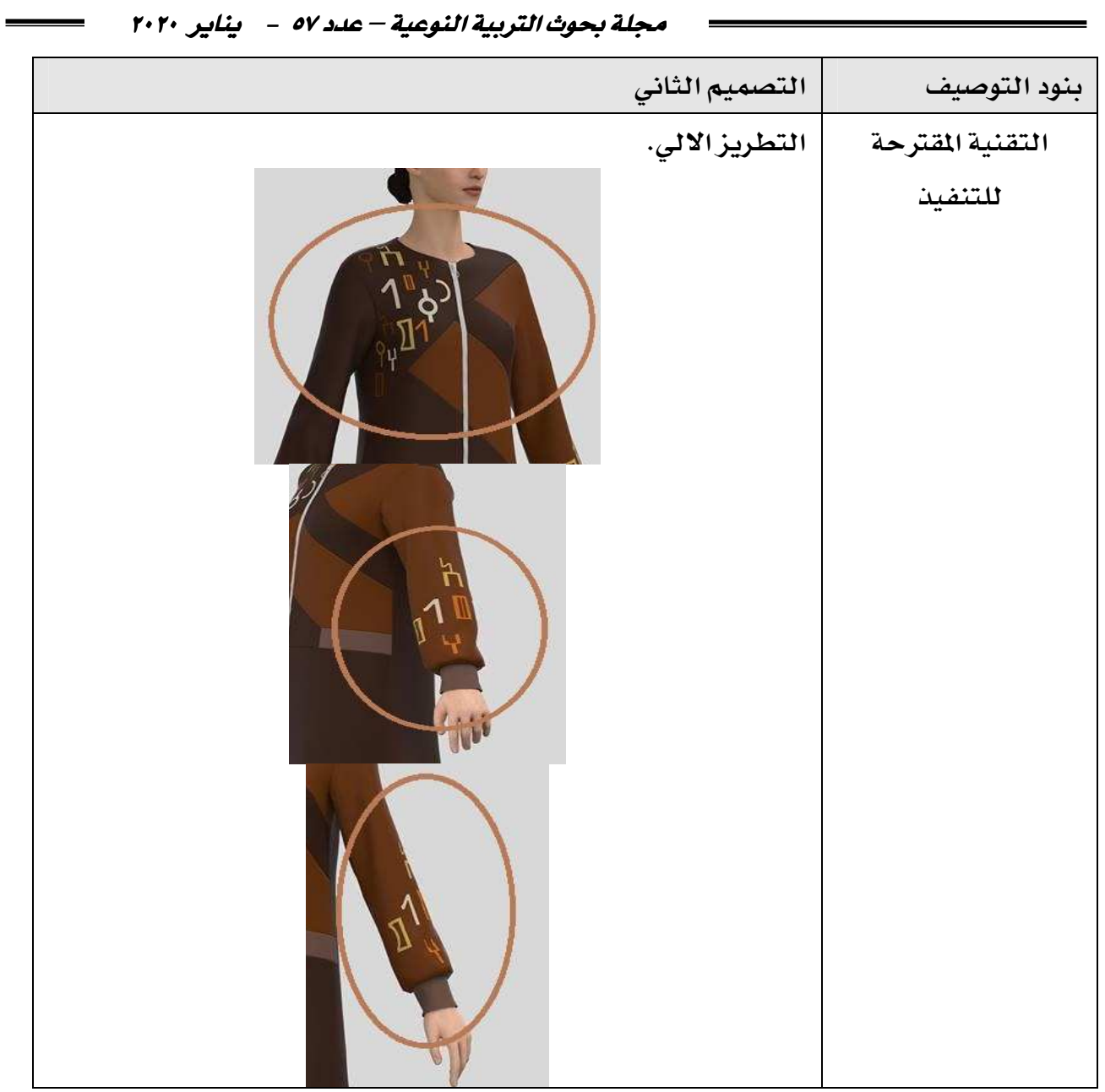



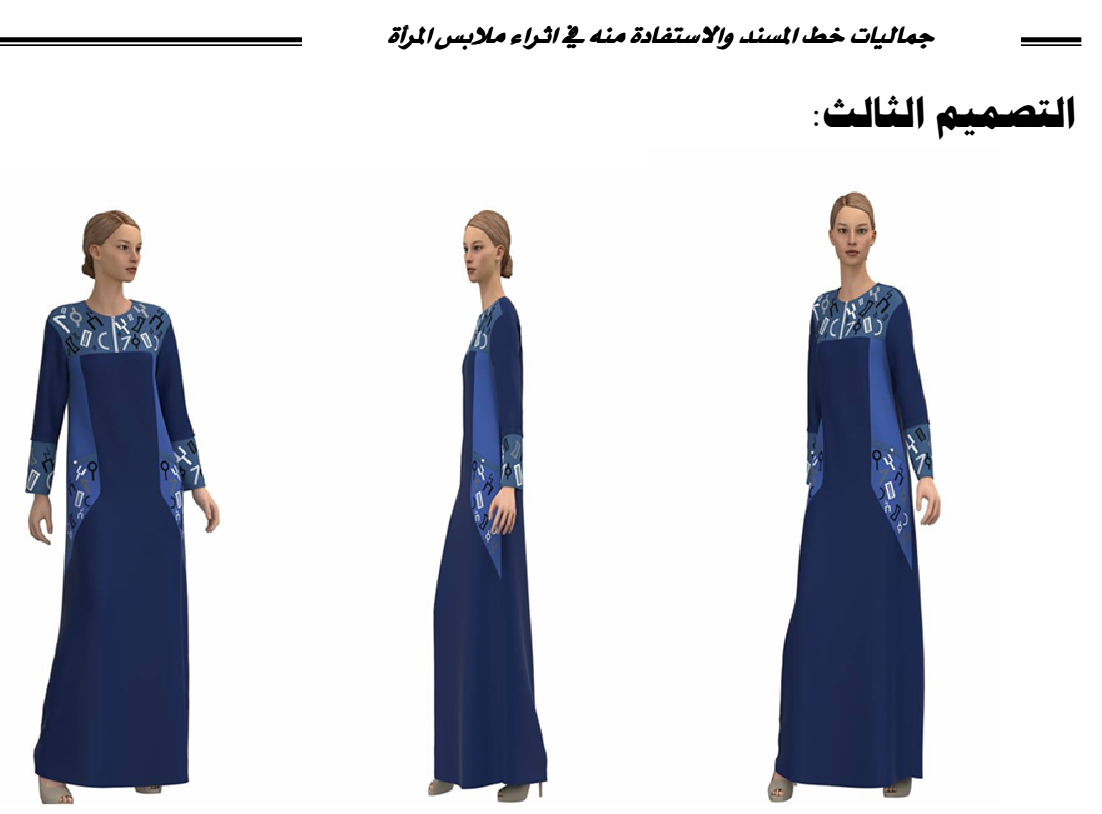

$$
\text { شكل (7) التصميم الثانث }
$$$$
\text { والجدول التالي يوضتح بنود التوصيف للتصهيم الثاني: }
$$

جدول (7) بنود توصيف التصميم الثالث

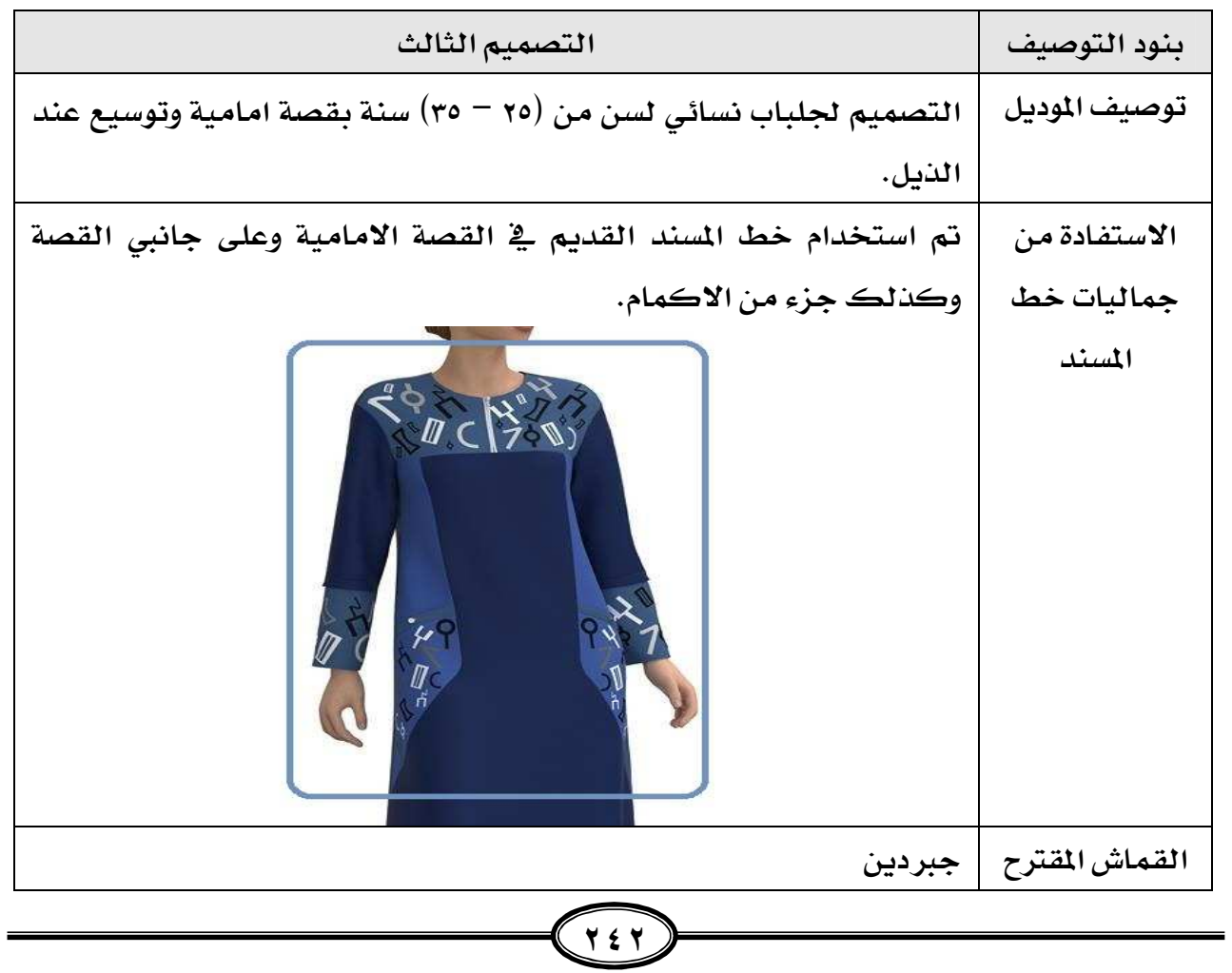




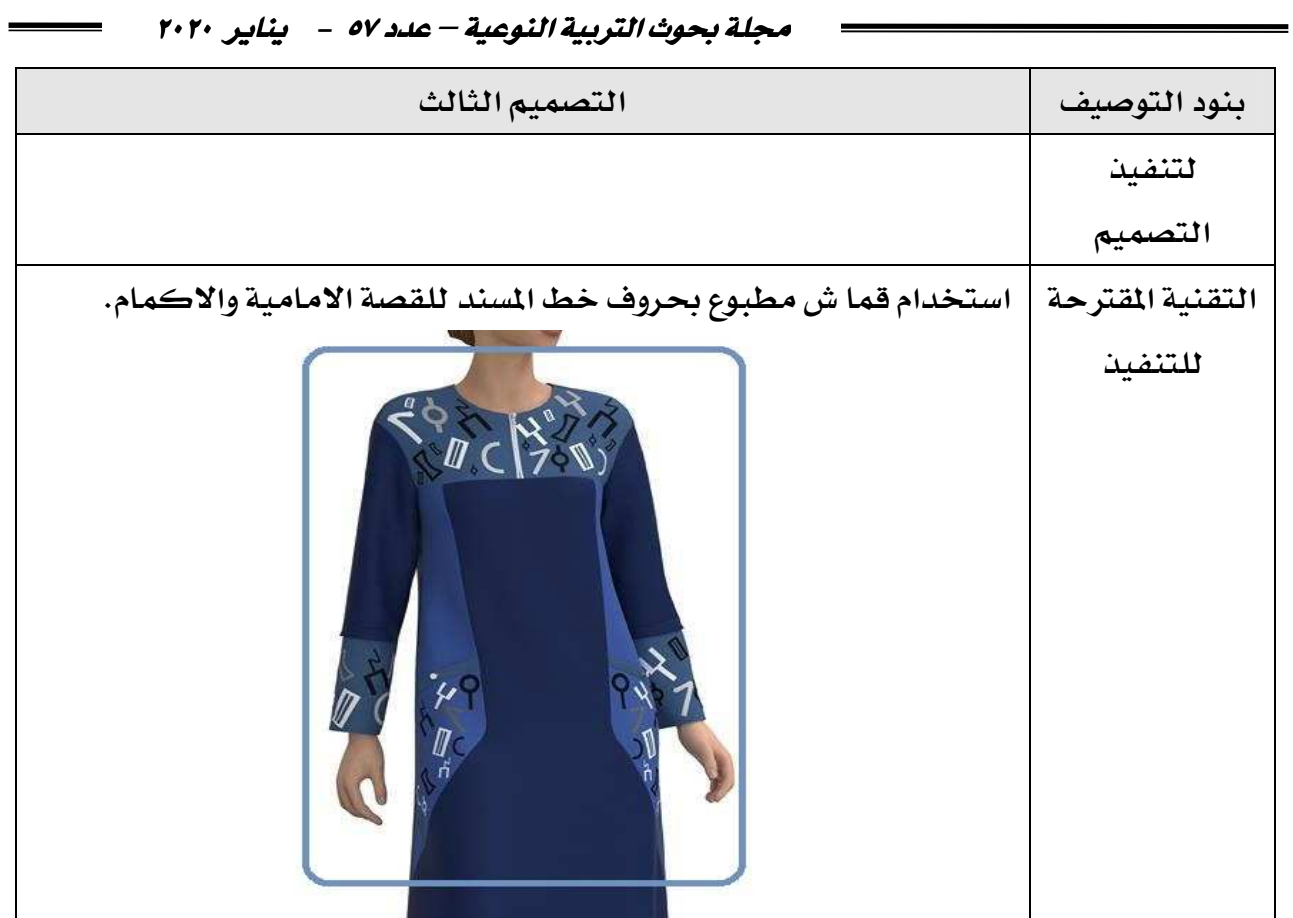

التصميم الرابع:
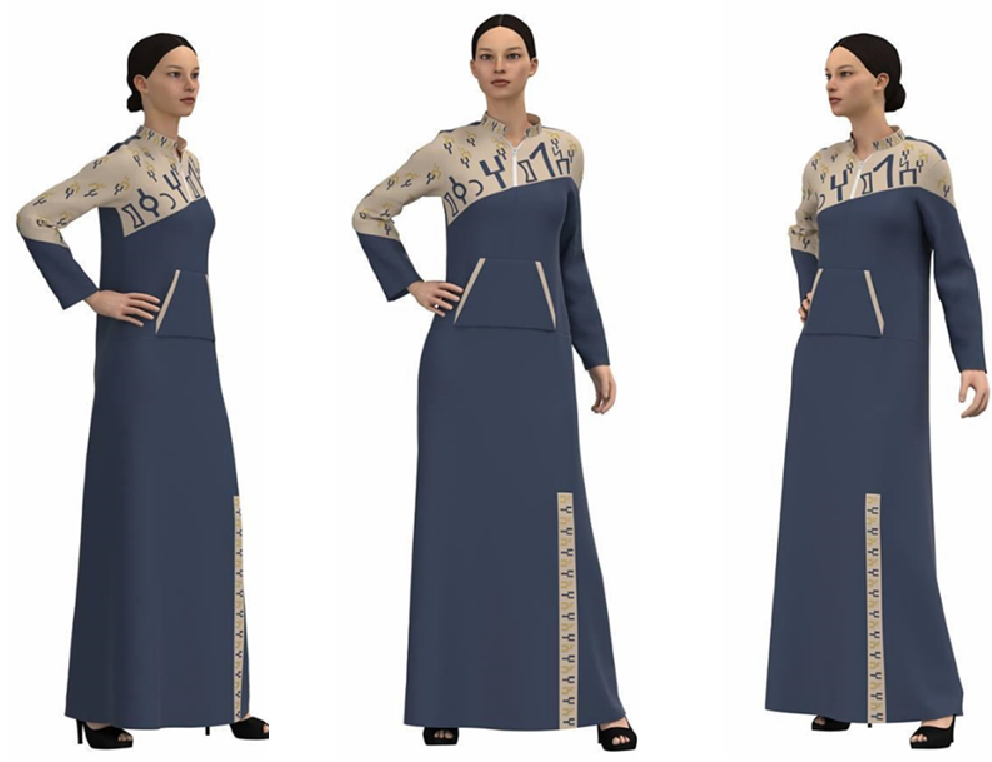

شكل (v) التصميم الرابع 


\section{جماليات خط المسند والاستفادة منه مِ اقراء ملابس المراة والجدول التالي يوضح بنود التوصيف للتصميم الرابع:}

جدول (v) بنود توصيف التصميم الرابع

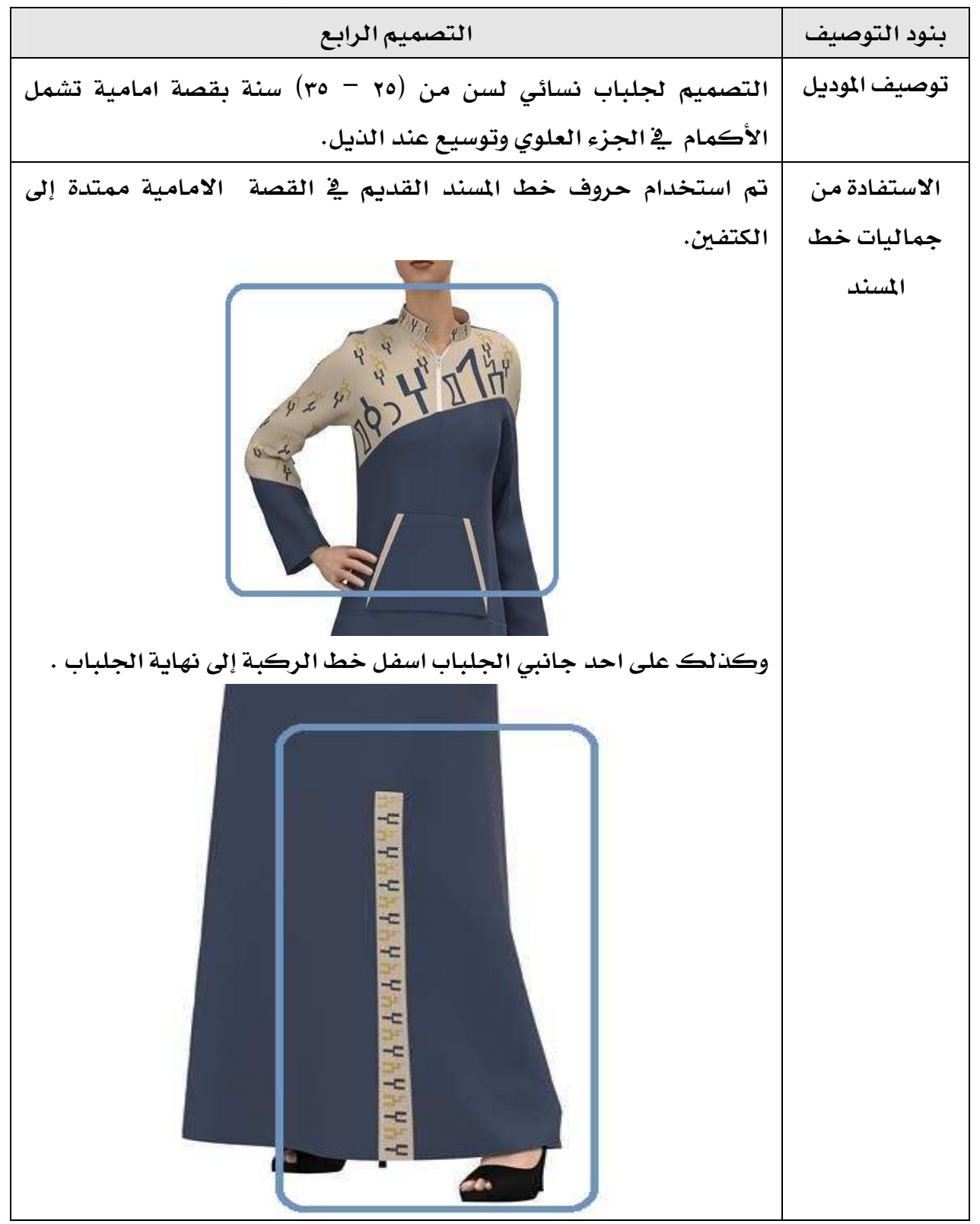



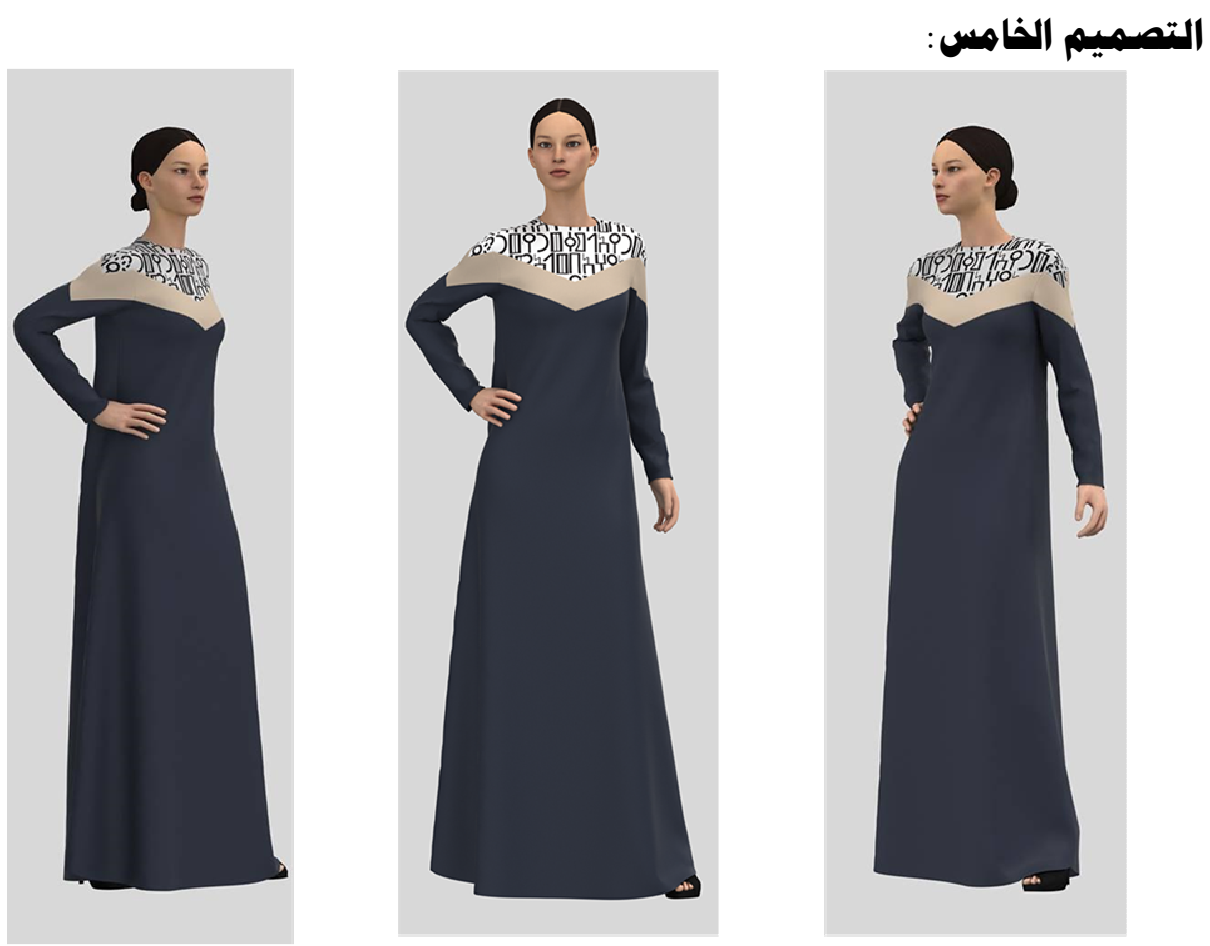

شكل (^) التصهيهم الخامس

والجدول التالي يوضسح بنود التوصيف للتصميهم الخامس:

جدول (^) بنود توصيف التصميهم الخامس

\begin{tabular}{|c|c|}
\hline التصهيم الخامس & بنود التوصيف \\
\hline 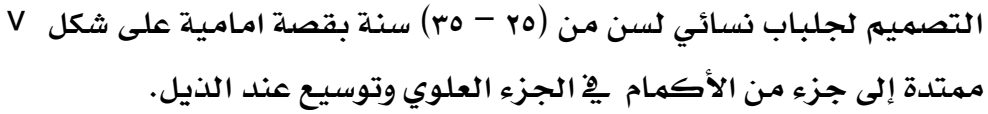 & توصيف الموديل \\
\hline تم استخدام حروف خط المسند القديهم يِّ القصة الامـامية مهتدة إلى جزء & جماليات خط خل \\
\hline
\end{tabular}




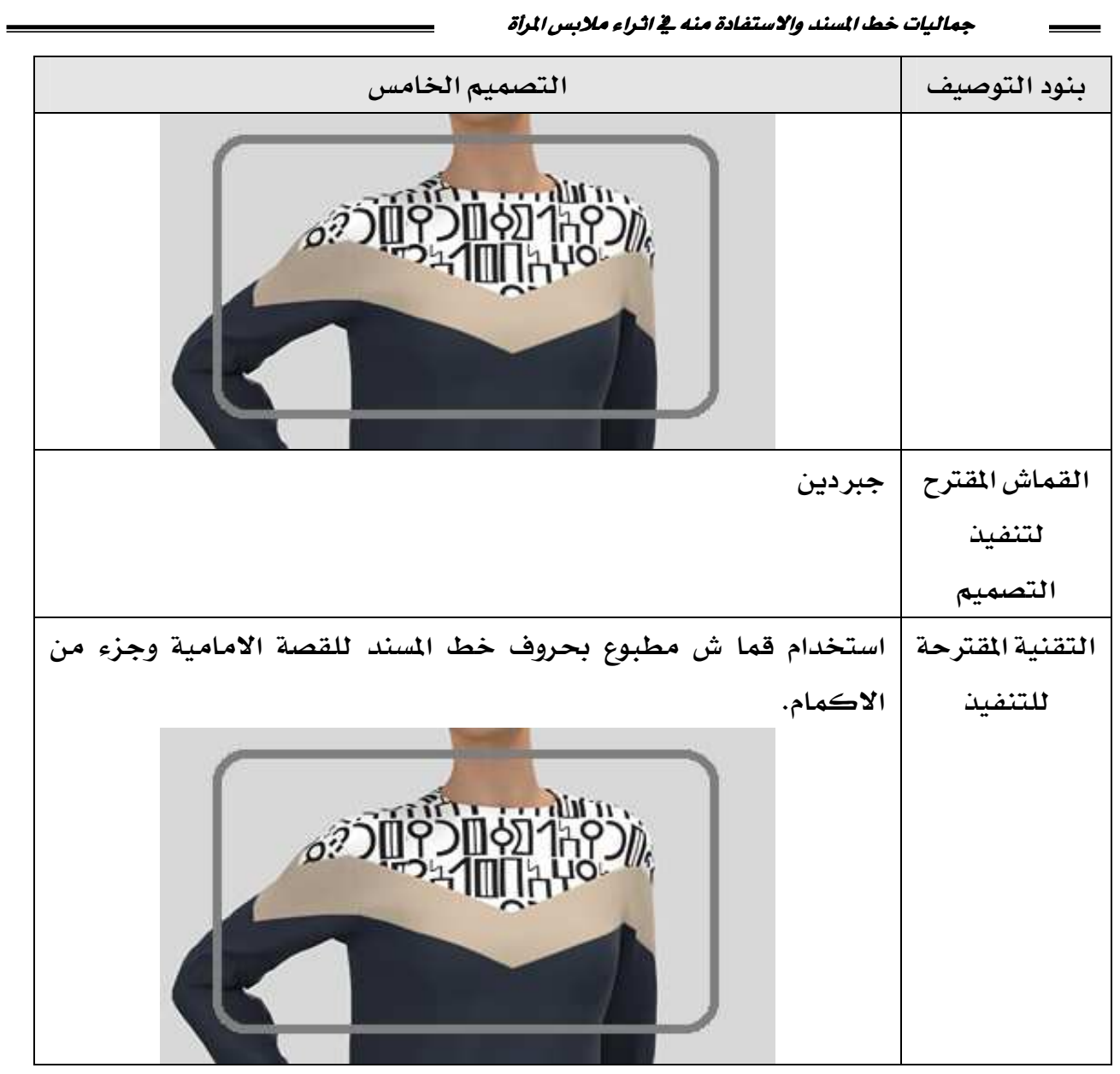

\section{المعالجات الإحصائية:}

بعد جمع البيانات وتفريغها تم تحليل البيانات وإجراء المعالجات الإحصائية باستخدام برنامج (SPSS) وفيما يلي بعض الأساليب الإحصائية المستخدمة لكثف العلاقية بين متغيرات واجتراء الدراسة واختبار صحة الفروض.

والمتوسطات الحسابية والانحراف المعياري، معامل ألفا كرو نباخ، والتجزئة النصفية لحساب ثبات أداة الدراسة، معامل ارتباط بيرسون، اختبار كروسكال والاس. 


\section{النتائج ومهناقشتها:}

تنص فرضية البحث على أنه "توجد فروق دالة احصائيا بين التصميمات المقترحة يِ ككلا من (الجانب الجمالي - الجانب الوظيفي) وفقا لآراء المتخصصين". وللتحقق من صحة فرضية البحث قامت الباحثة باستخدام اختبار كروسكال والاس وهو أحد الاختبارات اللامعملية، وهو بديل لتحليل التباين احادي الاتجاه ، ويستخدم إذا كان الغرض

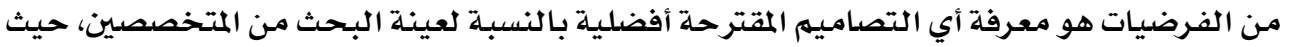
يتتم اجراء الاختبار على مرحلتين:

أ. التأكد من وجود فروق ذات دلالة إحصائية بين آراء المتخصصين للتصميمات المقترحة، وجدول (ه) يوضتح ذلك: جدول (q) قيمة اختبار كروسكال والاس

\begin{tabular}{|c|c|c|c|}
\hline مستوى الدلالة & درجات الحرية & قيمة كروسكال والاس & عدد التصميمات \\
\hline$\cdot, .0$ & $\varepsilon$ & $\left\langle Y_{1} \cdot 9 \varepsilon\right.$ & 0 \\
\hline
\end{tabular}

يتضح من الجدول السابق وجود فروق ذات دلالة إحصائية بىن آراء المتخصصىن فِ التصهىىمات المقترحة يٌْ تحقىق جهىع جوانب التصميهم. ب. ترتيب التصميمات المقترحة حسب متوسط الرتب لكل تصميم. وجدول ( ـ ) يوضح ذلكئ جدول (•) ترتيب التصميمات المقترحة

\begin{tabular}{|c|c|c|}
\hline ترتيب التصميم & متوسط الرتب & التصميم \\
\hline 0 & $\Lambda, Y_{1}$ & الأول \\
\hline r & Yl,o. & الثاني \\
\hline 1 & rI, rq & الثالث \\
\hline$r$ & $10, \cdot V$ & الرابع \\
\hline$\varepsilon$ & ir,qr & الخخامس \\
\hline
\end{tabular}

يتضح من الجدول السابق أنه قد تبين للباحثة أن التصميمين الأول والخامس قد جاءا يِ

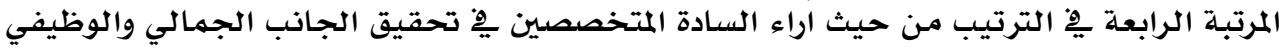

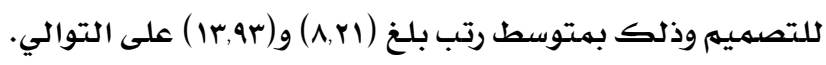

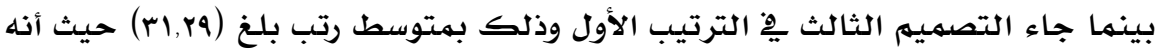

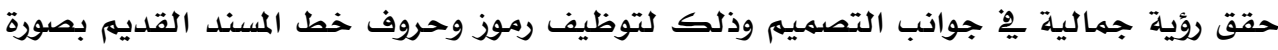

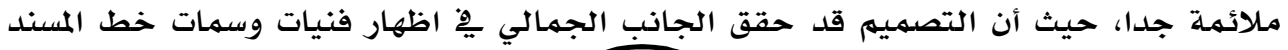


بتفاصيله،، كما انه حقق الترابط بين عناصر التصميهم بجانب الناحية الوظيفية وقد تميز بالابتكار

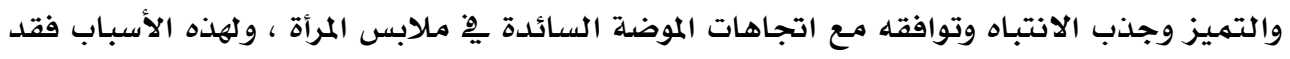

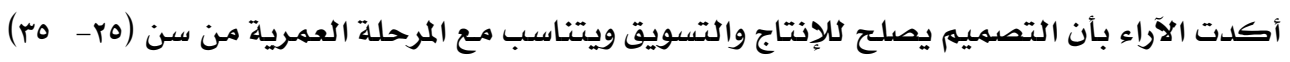

سنـة.

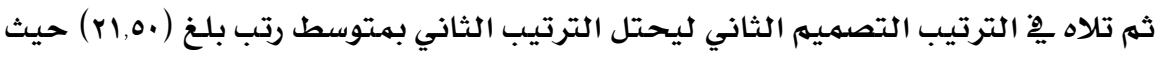

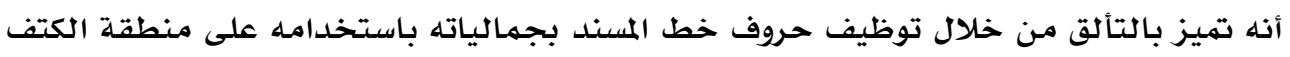

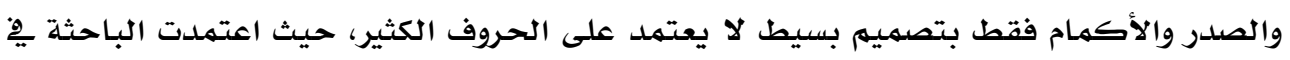

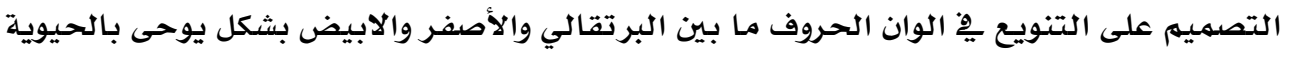

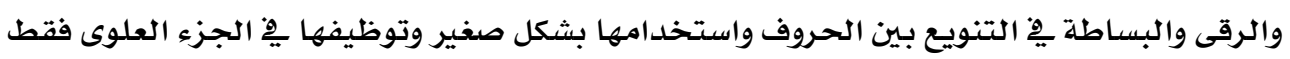

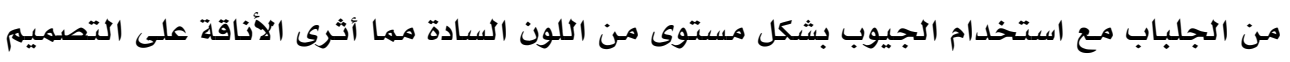

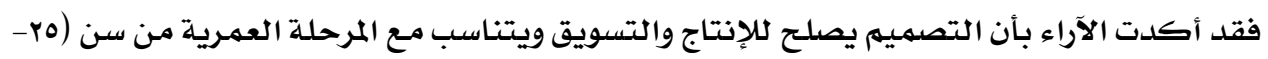

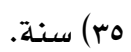

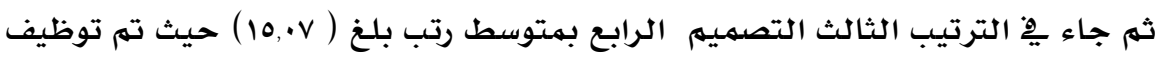

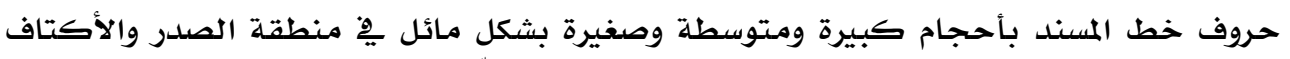

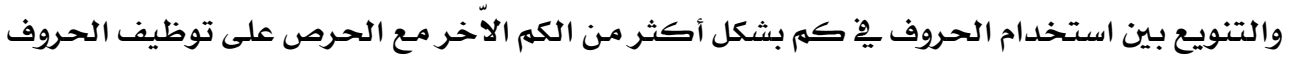

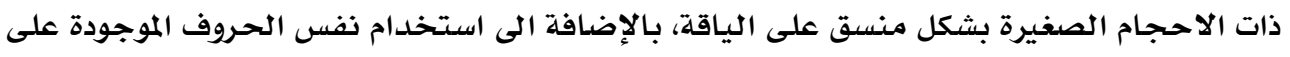

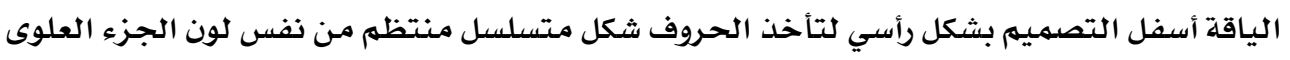

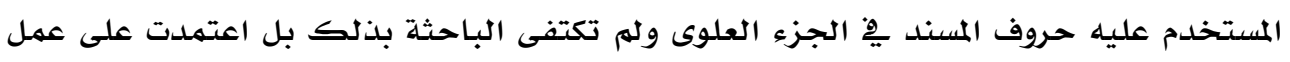

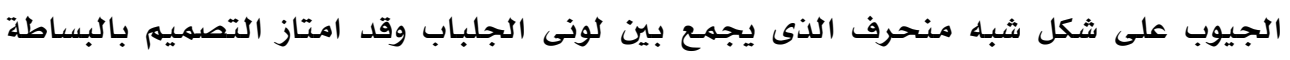

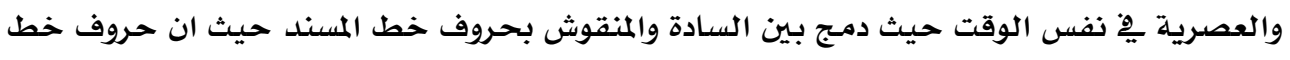

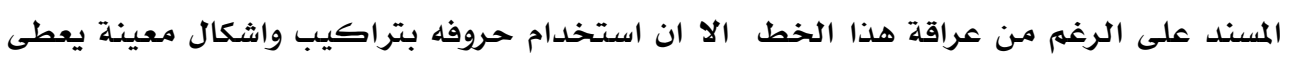

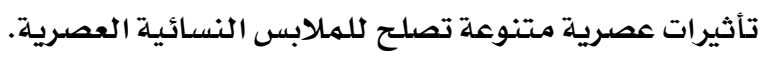

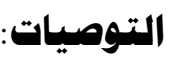

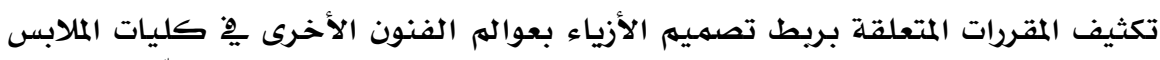

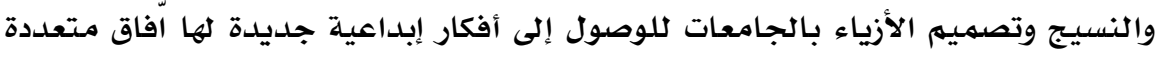

ومختلفة باختلاف الفنون المستلهمة منها.

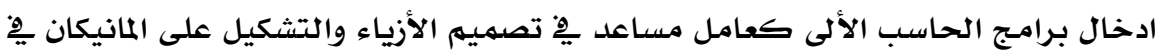

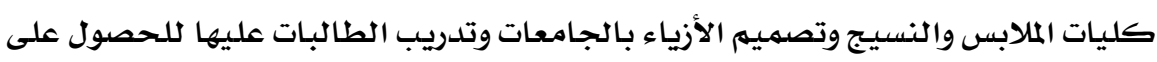

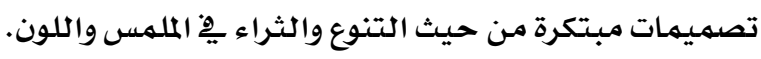

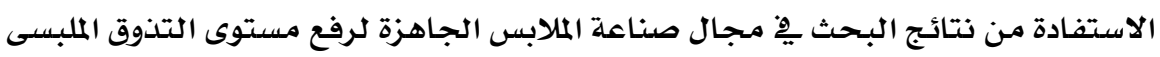
لدى المرأة. 
محاولة توظيف حروف خط المسند القديم مِّْن تنفيذ منتجات فنية أخرى مثل (المكملات -

$$
\text { قطع ملبسية اخرى). }
$$

\section{أولا المراجع العربية}

1. أبو البقاء المكبرى(1990) ): اللباب بِ علل البناء والإعراب، تحقيق غازى مختار طليمات، دار الفكر، بيروت.

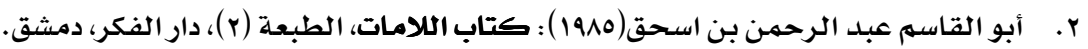

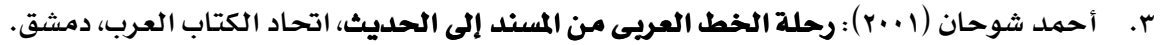

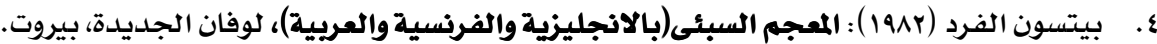
ه. بيتسون الفرد (1990): قواعد النقوش العربية الجنوبية "كتابات المسند"، ترجمة رفعت هزيم، مؤسسة حمادة للخدمات الجامعية، جامعة اليرموك، الأردن.

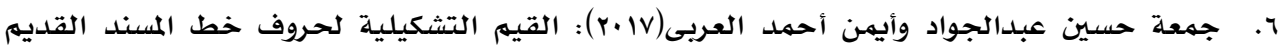

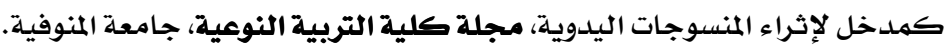
V. رشا محمد على حسن وسمر محمود جمعه (10.r): القيم الجمالية للكتابات والخطوط العربية

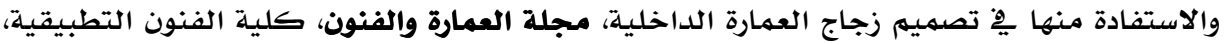
جامعة حلوان، القاهرة.

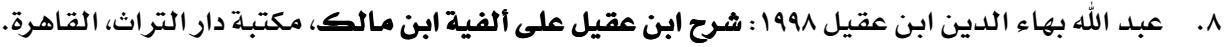

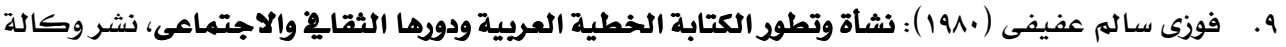
المطبوعات، الكويت.

• 1 . كريستيان روبان (1910) : آثار اليمن وتطور دراستها ـِّ: مختارات من النقوش اليمنية القديمة، المنظمة العربية للتربية والثقافة والعلوم، تونس.

11. محمد المرقطن (r..r): النقوش الخشبية القديمة، مصدر هام لدراسة التاريخ الحضارى لليمن القديم:

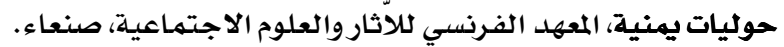

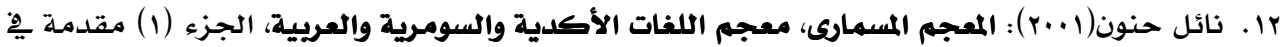
الكتابة المسمارية وفقه اللغتين السومرية والأكدية، بيت الحكمهة، بغداد.

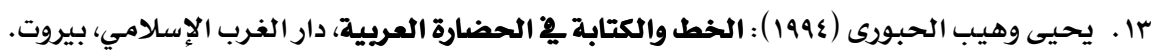
ثانيا المراجع الأجنبية

14. Marie Claude Simeone Senelle (2011): Modern South Arabian. In: Stefan Weninger (ed.): The Semitic Languages: An International Handbook . Mouton de Gruyter, Berlin. 